\title{
Meteorological Annual Report For 1996
}

by

c. H. Hunter

Westinghouse Savannah River Company

Savannah River Site

Aiken, South Carolina 29808

C. P. Tatum

\section{MASTER}

DOE Contract No. DE-AC09-89SR18035

This paper was prepared in connection with work done under the above contract number with the U.S. Department of Energy. By acceptance of this paper, the publisher and/or recipient acknowledges the U. S. Government's right to retain a nonexclusive, royalty-free license in and to any copyright covering this paper, along with the right to reproduce and to authorize others to reproduce all or part of the copyrighted papery

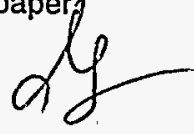




\section{DISCLAIMER}

Portions of this document may be illegible electronic image products. Images are produced from the best available original document. 
if

WSRC-TR-97-0214

METEOROLOGICAL ANNUAL REPORT FOR 1996 (U)

Charles H. Hunter

Charles P. Tatum

Technical Reviewer

A. H. While, Date $7 / 21 / 97$

Approval

Aghongi for R.P.Adchi Date for ii, 97

R. P. Addis, Manager, Atmospheric Technology Group

ALBi Date 7-22.97

A. L. Bond, Manager, Nonproliferation Technologies Section

August 1997

- Westinghouse Savannah River Company

Savannah River Site

Aiken, SC 29808

Prepared for the Department of Energy under contract no. DE-AC09-89SR18035 


\section{Executive Summary 1}

\section{Introduction 3}

General SRS Climate 3

SRS Meteorological Monitoring Program 3

Data Sources for the 1995 Annual Meteorological Report 4

Data Summaries 5

Overview 5

Detailed Summaries by Variable 5

Temperature 5

Precipitation 6

Relative Humidity 6

Wind 6

Barometric Pressure 7

Solar Radiation 7

References 7

\section{List of Tables}

Table 1.

Means and Extremes of SRS Meteorological.Data for 19969

Table 2. Monthly and Annual Average and Extreme Temperatures Since 196411

Table 3. Monthly and Annual Rainfall, 1967-96 12

\section{List of Figures}

Figure 1. Summary of Daily Data 2

Figure 2. 1996 Daily High and Low Temperatures 13

Figure 3. SRS Annual Average Temperature 1967-1996 14

Figure 4. SRS Monthly Average Temperature 14

Figure 5. Number of Freezing $\left(\angle 32^{\circ} \mathrm{F}\right)$ and Sweltering ( $>90^{\circ} \mathrm{F}$ ) Days 15

Figure 6. 1996 SRTC Daily Precipitation 16

Figure 7. SRTC Annual Precipitation 1967-1996 17

Figure 8. SRTC Monthly Precipitation 17

Figure 9. 1996 Daily High and Low Humidity 18

Figure 10. SRS Annual Average Humidity 1967-1997 19 
Figure 11. SRS Monthly Average Minimum Relative Humidity 19

Figure 12. 1996 Daily Average Wind Speed 20

Figure 13. Annual Wind Roses, 1995 and 1987-91 21

Figure 14. Seasonal Wind Roses for 199622

Figure 15. $\quad$ Seasonal Wind Roses, 1987-91 23

Figure 16. Annual Wind Rose for A, C, D, and F Towers, 199624

Figure 17. Annual Wind Rose for H, K, L, and P Towers, 199625

Figure 18. 1996 Daily Average Barometric Pressure 26

Figure 19. $\quad 1996$ Daily Solar Radiation 27

Attachment A. Map of the Savannah Biver Site Showing the Location of the Meteorological Towers 28

Appendix A. Joint Frequency Tables of Wind Speed by Wind Direction 29

$$
\begin{aligned}
& \text { " }
\end{aligned}
$$

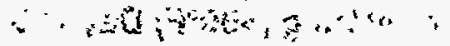

$$
\begin{aligned}
& \text { Ef } \\
& \text {; }
\end{aligned}
$$

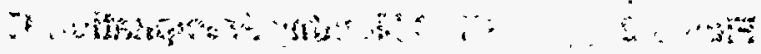

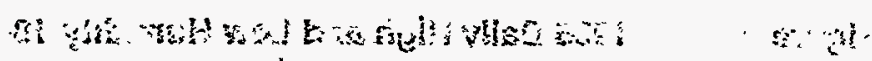

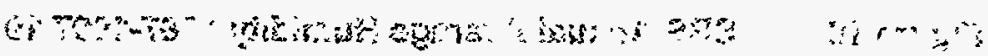




\section{Executive Summary}

An analysis of meteorological data collected at the Savannah River Site (SRS) in 1996 shows that overall weather conditions for the year were characterized by below normal temperatures and near normal precipitation. The average temperature for the year, $62.2^{\circ} \mathrm{F}$, was the lowest observed at SRS for the 33 years in which temperature data are available (196496). Temperature extremes for 1996 ranged from a minimum of $10^{\circ} \mathrm{F}$ on February 5 to a maximum of $100^{\circ} \mathrm{F}$ on July 2.

Monthly rainfall was near or slightly below average each month except March and August which had considerably above average rainfall. The maximum 24-hour rainfall was 2.47 inches on July 5. Daily rainfall in excess of 2 inches occurred on July 5 and August 25. These rainfall events were associated with slow moving cold fronts. Approximately one inch of snow was recorded in the SRS area on February 4.

The annual average wind speed, based on data collected at the Central Climatology meteorology tower, was about $10 \%$ higher than the average for a previous 5-year period (1987-91). The 1996 data also showed a slightly higher frequency of west to southwest winds and a slightly lower frequency of northeast winds than was observed in the earlier 5-year period. A winter storm that formed over Alabama and moved northeastward through east Tennessee March 18-19 produced the most notable period of sustained strong winds. Daily and 15-minute average wind speeds of 16 miles per hour (mph) and $26.6 \mathrm{mph}$, respectively, were recorded at Central Climatology.

Monthly average relative humidity for the year was lowest during the spring months (57\% in April) and highest in the summer and early fall (81\% in August). The average relative humidity for the year was $69 \%$ and the average daily minimum relative humidity, which typically occurs during the afternoon, was $45 \%$.

Tropical Storm Josephine moved through eastern portions of Georgia and South Carolina on October 8 producing a total rainfall at SRS of about 1.8 inches. The highest 15-minute average wind recorded during the passage of this storm was $19.8 \mathrm{mph}$; the maximum instantaneous speed during this period was $35 \mathrm{mph}$. Hurricanes Bertha and Fran struck the southeast U.S. coast near Wilmington, North Carolina in July and September, respectively; however, these storms had little adverse affect on the weather at SRS.

Summary plots of 1996 daily minimum/maximum temperature, 24-hour total precipitation, daily minimum relative humidity, and daily average wind speed are shown in Figure 1.

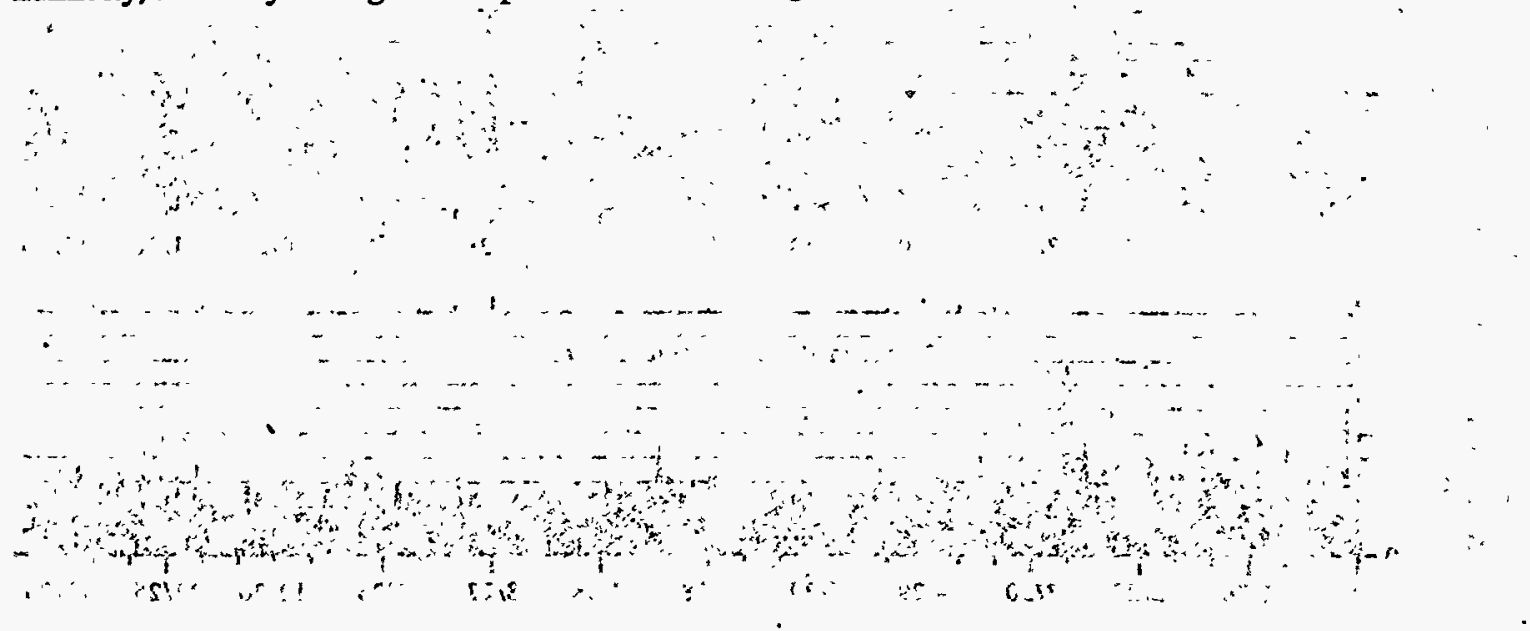


FIGURE 1. SUMMARY OF DAILY DATA FOR 1996
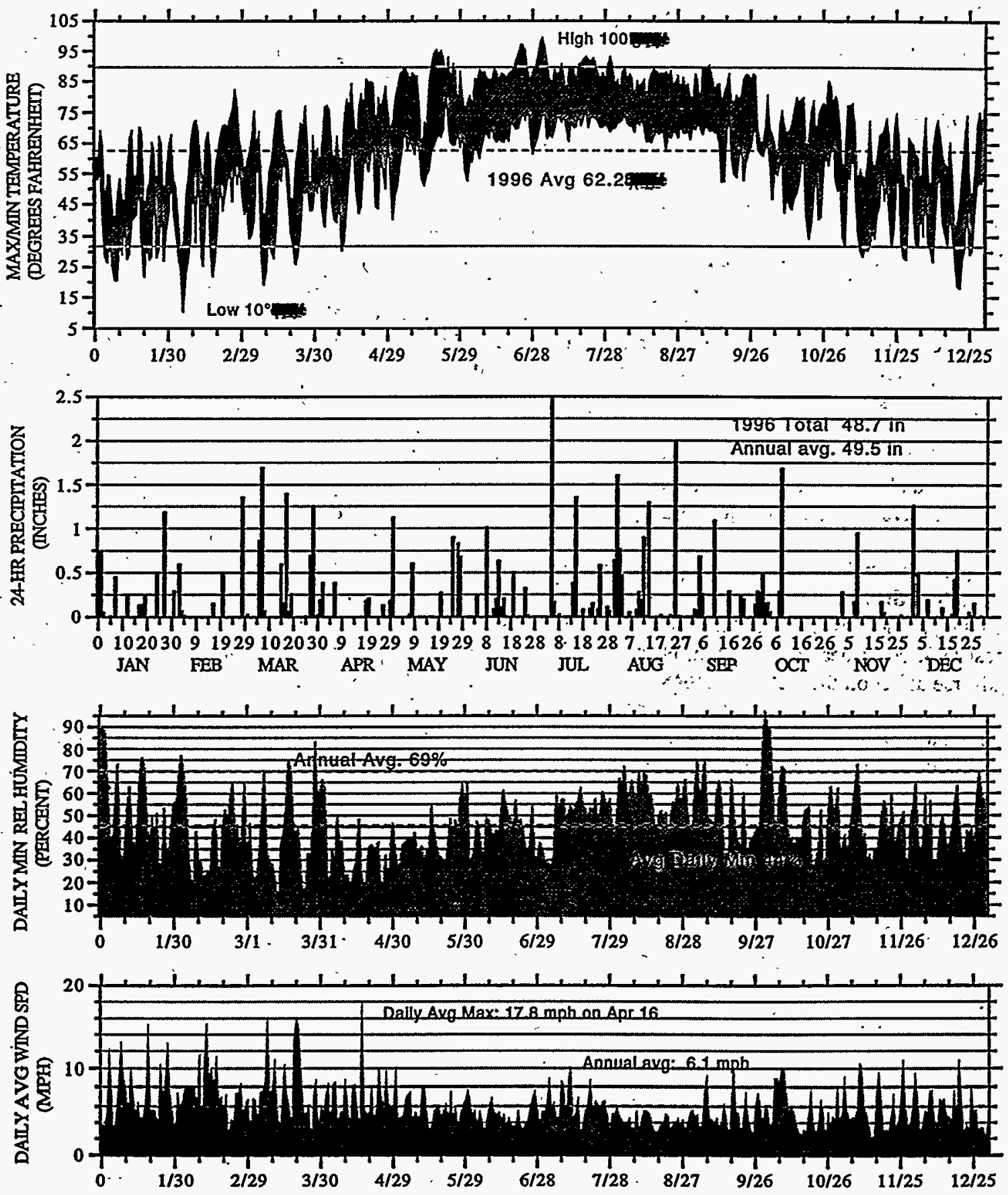


\section{Introduction}

\section{General SRS Climate}

The southeastern U.S. has a humid subtropical climate characterized by relatively short, mild winters and long, warm, and humid summers (Oliver and Fairbridge 1987).

Summerlike weather conditions typically last from May through September, when the area is under the influence of the western extension of the semi-permanent Atlantic subtropical anticyclone (i.e., the 'Bermuda' high). Winds in summer are light and cold fronts generally remain well north of the area. Daily high temperatures during the summer months exceed $90^{\circ} \mathrm{F}$ on more than half of all days on the average. The persistent heat and humidity often result in scattered afternoon and evening thunderstorms.

The influence of the Bermuda high begins to wane during the fall, resulting in lower humidity and more moderate temperatures. Average rainfall during the fall is usually the least of the four seasons.

The weather is quite changeable during the winter months, as mid-latitude low-pressure systems and fronts migrate through the region. Weather conditions frequently alternate between warm, moist, subtropical air from the Gulf of Mexico. region and cool, dry polar air. Although outbreaks of Arctic air occasionally can affect SRS, the extremely - cold conditions associated with these air.masses are moderated by the Appalachian Mountains to the north and northwest. As a result, less than one-third of winter days have minimum temperatures below freezing on the average and days with temperatures below $20^{\circ} \mathrm{F}$ are infrequent. Measurable snowfall is rare.

Spring is characterized by a higher frequency of occurrence of tornadoes and severe thunderstorms than the other seasons. Although spring weather is somewhat windy, temperatures are mild and the humidity is relatively low.

Detailed descriptions of the climate of the SRS are contained in Hunter (1989), Hoel (1984), and Weber (1993).

\section{SRS Meteorological Monitoring Program}

The Atmospheric Technologies Group (ATG) of SRTC collects, archives, and analyzes basic meteorological data supporting a variety of activities at SRS including the design, construction, and operation of nuclear and nonnuclear facilities, emergency response, environmental compliance, resource management, and environmental research.

The ATG maintains a network of eight 200-foot meteorological observation towers located at A, C, D, F, H, K, L; and $\mathrm{P}$ Areas. Additional meteorological instrumentation is located at the Central Climatology facility near $N$ Area, which includes a 200-foot observation tower and on the 1000-foot WJBF-TV tower near Beech Island, South Carolina. Measurements of wind speed, direction, turbulence, air temperature, and dew point temperature are taken at a height of 200 feet above ground on all of the site towers. Identical measurements are made on the Central Climatology tower at heights of $13,58,116$, and 200 feet. Additional measurements conducted at Central Climatólogy consist of precipitation, evaporation, solar radiation, barometric pressure, and soil temperature. At the WJBFTV tower, measurements of wind speed, direction, turbulence, and air temperature are recorded at seven levels through 1000 feet. A measurement from each sensor in the network is taken at 1.5 second intervals by a centrally located computer. Fifteen-minute averages and standard deviations are computed and stored in a relational database.

Additional measurements of temperature and relative humidity are taken with a hygrothermograph mounted in a standard National Weather Service 'cotton region' instrument shelter adjacent to Building 773-A. Data from the - hygrothermograph are continuously provided to a strip chart recorder. Daily maximum and minimum values of temperature and relative humidity are manually extracted from the strip, charts and entered into a computer data 
base. Daily precipitation is measured with a plastic wedge rain gauge located adjacent to the instrument shelter. Rainfall measurements are taken once per day, usually around 9 AM. Data collection at or near the 773-A site has been conducted since 1952 and the data have been used extensively in basic descriptions of the SRS climate. The data recorded at this site are subject to a manual quality control inspection to ensure the reasonableness of the data; nevertheless, some errors may be present in the data record.

A map showing each of the measurement locations is given in Attachment A. Parker and Addis (1994) and Kurzeja (1993) provide detailed descriptions of the NTS meteorological monitoring facilities and instrumentation.

\section{Data Sources for the 1996 Annual Meteorological Report}

This report contains tabular and graphical summaries of data collected during 1996 for temperature, precipitation, relative humidity, wind, barometric pressure, and solar radiation. Most of these data were collected at the Central Climatology facility. (Relative humidity is calculated from measurements of dew point temperature.) Summaries of temperature and relative humidity were generated with data from the lowest level of measurement at the Central Climatology tower (13 feet above ground). Wind speed summaries were generated with data from the second measurement level (58 feet above ground). Wind speed measurements from this level are believed to best represent open, well exposed areas of the Site. In addition, seasonal and annual summaries of the joint frequency of occurrence of wind direction sector by wind speed category (i.e., wind roses) are provided for the Central Climatology tower (200-foot level only) and each of the eight area towers.

Valid data recovery for the onsite monitoring towers in 1996 ranged from $91 \%$ at the F-Area and K-Area towers to 96\% at the A-Area and P-Area towers. Temperature and precipitation.data from the 773-A instrument shelter were substituted for about five dāys of missing record at Central Climatology.

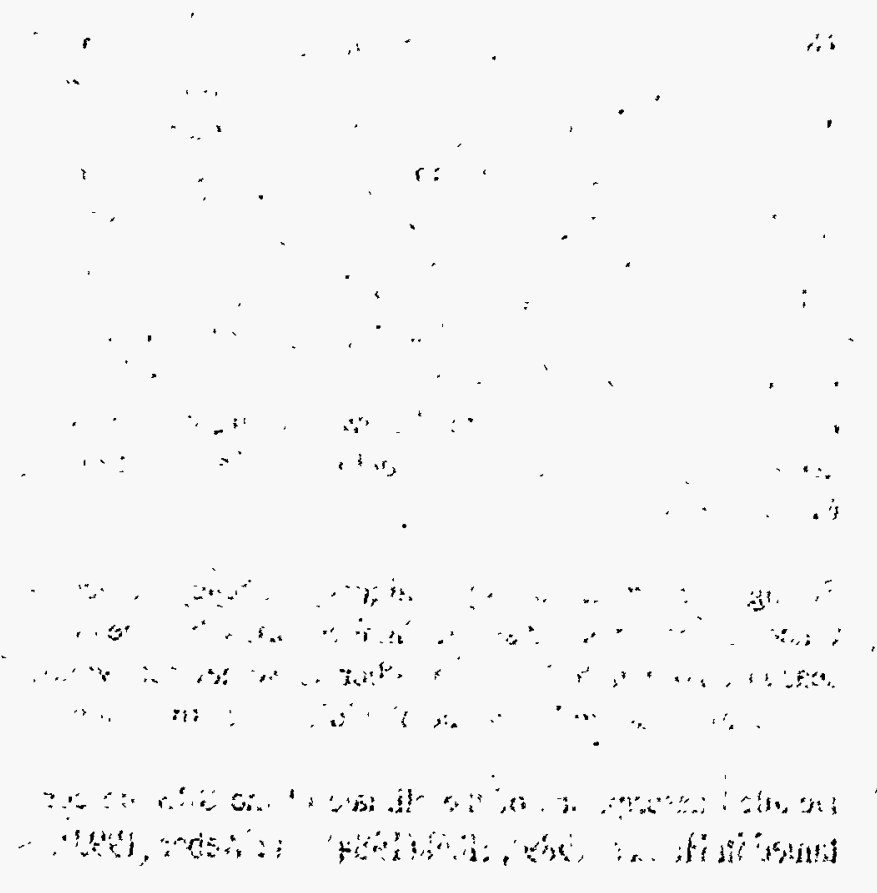




\section{Data Summaries}

\section{Overview}

Annual and monthly averages and extremes for each of the meteorological variables summarized this report are given in Table 1. Plots of daily minimum and maximum temperatures, 24-hour total precipitation, daily minimum relative humidity, and daily average wind speed are shown in Figure 1.

Frequent periods of relatively cool weather affected much of the central and eastern U.S. during 1996 (NOAA 1997). These conditions were the result of a strong and persistent negative phase North Atlantic oscillation, an unusual hemispheric circulation pattern which produces an intensification and southward migration of the polar jet stream across North America. This pattern has occurred only twice in recent years (Halpert 1997).

Other than several days of cold and cloudy weather early in the month-the result of a major winter storm in the northeast U.S.-January was characterized by seasonal weather with monthly temperatures and rainfall only slightly bélow average.

The strongest of a series of Arctic high-pressure systems that affected the eastern U.S. during the first part of the year occurred in early February. Temperatures at SRS on February 4 remained below freezing throughout the day (high of $31^{\circ} \mathrm{F}$ ), then dropped to a low of $10^{\circ} \mathrm{F}$ on the morning of February 5. A temporary northward shift in the polar jet brought somewhat warmer weather during the latter half of February. As a result, overall temperatures for the month were above average $\left(+1.0^{\circ} \mathrm{F}\right)$ and total rainfall " was below average ( -1.54 inches)

Cold weather returned in March and persisted throughout "much of the rest of the year. The average temperature for

“- March 1996, 50.6\%, was the second lowest average tem-

perature for the month in the 33 -year period for which temperature data are available (1964-96). Low tempera-

${ }^{-3}$ tures in the imid 20s occurred as late as March 22: A winter

L storm that formed over Alabama and east Tennessee

2. March '18-19' prodiuced the 'móst' notable period of 'sus-

- tained strong winds of the year. Daily and 15-minute aver-

- age wind speeds of 16 miles per hour (mph) and $26.6 \mathrm{mph}$,

"respectively," were recorded at the Central Climatology meteorological tower."
Temporary shifts in the prevailing atmospheric circulation pattern brought relatively hot weather on two occasionsmid-May and late June through early July. The hottest temperature of the year, $100^{\circ} \mathrm{F}$, was recorded July 2 . Otherwise, summer temperatures remained exceptionally cool. The average temperature for the months of June, July, and August was $3.0^{\circ} \mathrm{F}$ below the 30 -year average for that three-month period. The average temperature for August, $76.0^{\circ} \mathrm{F}$, was the second lowest since 1964 . High temperatures during the summer reached $90^{\circ} \mathrm{F}$ or higher on only 36 days, less than $50 \%$ of the annual average total of 76 days.

The unusually cool weather continued through the fall months (September-November). The average temperature for the fall was the second lowest since $1964,3.6^{\circ} \mathrm{F}$ below the 30-year average for this three-month period. Tropical Storm Josephine moved through eastern portions of Georgia and South Carolina on October 8, producing a total rainfall at SRS of about 1.8 inches. The highest wind .recorded during the passage of this storm was $19.8 \mathrm{mph}$ with a gust of $35 \mathrm{mph}$. Other than the heavy rains occurring with Josephine, the fall months were relatively dry.

A somewhat permanent shift northward in the polar jet toward the end of the year resulted in a return to near average temperatures and rainfall for December.

\section{Detailed Summaries by Variable}

\section{Tèmperature}

Figure 2 shows a plot of 1996 daily minimum and maximum temperature. Annual and monthly average temperatures for the 30-year period 1967-96 are summarized in Table 2 and plotted in Figures 3 and 4.

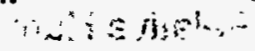

Temperatures for 1996 ranged from a minimum of $10^{\circ} \mathrm{F}$, observed on the morning of February 5 , to aximum of $100^{\circ} \mathrm{F}$, observed on the afternoon of July 2 . The average temperature for 1996 was $62.2^{\circ} \mathrm{F}$, which is about 2.5 degrees below the average for the 30-year period $1967-96$.

(Note that monthly and annual average temperatures for 1967-94, summarized in Table 2 and Figures 3 and 4, should be considered approximate values os they are based on averages of observed daily minima and maxima at the 773-A instrument shelter. The ayerage temperazures 
given for 1995-96 are based on a near continuous record of 15-minute values at the Climatology Site.)

July was the warmest month of the year with an average daily maximum of $90.2^{\circ} \mathrm{F}$ and an average daily minimum of $71.1^{\circ} \mathrm{F}$; January was the coldest month with an average daily high of $57.0^{\circ} \mathrm{F}$ and an average daily low of $35.4^{\circ} \mathrm{F}$. Monthly average temperatures for 1996 were below their respective 30-year averages for each month except February and May. March, April, and the four-month period August through November was particularly cool with monthly average temperatures generally more than $3^{\circ} \mathrm{F}$ below 30-year mean values. High temperatures greater than $90^{\circ} \mathrm{F}$ were observed on only 36 days during the year (see Figure 5). The average number of days per year with temperatures equal to or exceeding $90^{\circ} \mathrm{F}$ is 74 . Nearly half of the total 'hot' days for 1996 occurred in July (17 of 36 days). Minimum temperatures below $32^{\circ} \mathrm{F}$ were observed on 54 days, well above the :30-year mean of 37 'freeze days' per year.

\section{Precipitation}

Daily precipitation for 1996. is summarized graphically in Figure 6. Annual and monthly rainfall since 1967 is summarized in Table 3 and plotted in Figures 7 and 8, respectively.

Rainfall of 0.01 inches or more was observed on 121 days during the year. The maximum 24-hour rainfall was 2.47 inches on July 5. Daily rainfall in excess of 2 inches occurred on July 5 and August 25.

Total precipitation for 1996 was 48.7 inches, which is about 0.8 inches below the average annual precipitation over the 30-year period 1967-96. Above average rainfall was recorded in four of the 12 months (March and July through September). Rainfall totals for March (7.27 inches) and August (7.70 inches) were the fifth and sixth highest, respectively, over the period of record 1952-96.

\section{Relative Humidity}

A plot of daily minimum and maximum relative humidity is shown in Figure 9. Annual average relative humidity and monthly average minimum relative humidity, is plotted in $\therefore$ figures 10 and $11^{i}$, respectively

Note: Relative humidity is defined as the ratio of the vapor pressure of water in the ambient air to the saturation vapor pressure. As the ambient temperature cools to the dew point temperature (assuming constant pressure), morming values of relative humidity can often approach "100\%, even when the moistite content of the atmosphere is relatively low. Therefore, daily minima of relative humidity are emphasized in the following discussion, as a more meaningful indicator of prevailing atmospheric moisture.

The lowest relative humidity observed in 1996 was 14\% March 13, associated with a strong high pressure over the southeast U.S. Daily minimum relative humidity was frequently less than $30 \%$ during the winter and spring months but rarely below $40 \%$ during the summer and early fall.

The average relative humidity for 1996 was $69 \%$, slightly higher than the average value of $68 \%$ for the 30 -year period 1967-96. The average daily maximum for 1995 was $88 \%$, and the average daily minimum was $44 \%$. Monthly average relative humidity ranged from $57 \%$ in April to $81 \%$ in August. The monthly averages of daily minimum relative humidity were below 30-year means in April, November, and December and greater than the 30-year means in July through October.

\section{Wind}

A plot of daily average wind speed for 1996 is shown in Figure 12. The annual average wind speed for.1996 was 6.1 mph (measured at an elevation of 58 feet above ground). Monthly average speeds ranged from $7.7 \mathrm{mph}$ in March to $4.3 \mathrm{mph}$ in August. A winter storm that formed over Alabama and east Tennessee March 18-19 produced the most notable period of sustained strong winds. Daily and 15-minute average wind speeds of 16 miles per hour (mph) and $26.6 \mathrm{mph}$, respectively, were recorded at the Central Climatology meteorological tower. The maximum instantaneous gust for the year, $50 \mathrm{mph}$, occurred during a thunderstorm on July 15.

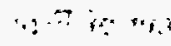
in! $\vdots$.

Annual and seasonal wind rose plots for wind data collected at the 200-foot level of the Central Climatology tower are shown in figures 13 and 14, respectiyely. Annual and seasonal wind roses for a five-year data set, 1987-91, are shown in Figures 13 and 15, respectively. (The fiveyear wind rose data set is comprised primarily of measurements from the H-Area tower, approximately three, miles northeast of Central Climatology). a - a

${ }_{73}$ The annual wind rose for 1996 shows west and westsosouthwest winds occurred about $2 \%$ more often, and $\because$ northeast and east-northeast winds, gccurred about $2 \%$ less $\rightarrow-5$ often than were observed during the five-year period 1987$\therefore 91$ (Figure 13). These anomalies, were due primarily to a series of strong polar high pressure areas that affected the southeast U.S. during the winter and spring months. 
The annual average wind speed at the 200-foot level of the Climatology tower was $9.5 \mathrm{mph}$, slightly higher than the five-year average of $8.7 \mathrm{mph}$.

Wind roses for the A-, C-, D-, and F-Area towers and for the $\mathrm{H}-, \mathrm{K}-, \mathrm{L}_{-}$, and P-Area towers are shown in Figures 16 and 17, respectively. Wind roses for each of the area towers are similar, except for the D-Area tower. Since the D Area is located in the Savannah River valley, channeling of the wind by nearby higher terrain to the northeast and southwest resulted in slightly higher frequencies of northwest and southeasterly winds than was observed at the other towers. Annual average wind speeds for the area towers ranged from $7.9 \mathrm{mph}$ at the D-Area tower to 9.7 $\mathrm{mph}$ at the C-Area tower. The frequency statistics used to generate the wind rose plots in Figures 13-17 are summarized in Appendix A.

\section{Barometric Pressure}

Average barometric pressure for 1996 was 1006.1 millibars $(\mathrm{mb})$. The lowest daily average value, $981 \mathrm{mb}$, occurred on October 8 as the remnants of tropical storm Josephine moved to the east of the site. The highest daily average value, $1028 \mathrm{mb}$, occurred on March 10 during the passage of a strong Arctic high pressure. Daily average barometric pressure is plotted in Figure 18. The greatest variability in daily average pressure occurred in January through March and again in November through December.

\section{Solar Radiation}

The average daily total solar radiation for the year was $\mathbf{3 8 8}$ langleys per day (ly/day). Monthly average daily values ranged from 575 ly/day in May to 223 ly/day in January and December. A comparison of observed daily solar radiation to a theoretical, clear sky maximum was performed to infer relative cloudiness. The theoretical values were estimated from tables in Budyko (1974). April was the 'sunniest' month with an observed average daily solar radiation of $76 \%$ of the theoretical maximum for the month. January was the 'cloudiest' month with an observed average daily solar radiation of $52 \%$ of the theoretical maximum. Daily total solar radiation is plotted in Figure 19.

\section{References}

Budyko, M. I., Climate and Life, Academic Press, New York, New York (1974).

Hoel, D. D., Climatology of the Savannah River Plant Site, DP-1679, E. I. du Pont deNemous (1984).

Hunter, C. H., A Climatological Description of the Savannah River Site, WSRC-RP-89-313, Westinghouse Savannah River Company (1990).

Kurzeja, R. J., The Savannah River Technology Center Research and Development Climatology Center, WSRC-TR-93-596, WSRC (1993).

National Atmospheric and Atmospheric Administration (NOAA), Daily Weather Maps for 1995, Climate Analysis Center, Washington, DC.

Oliver, J. E., and R. W. Fairbridge, ed., The Encyclopedia of Climatology, Von Nostrand Reinhold, New York, NY (1987).

Parker, M. J., and R. P. Addis, SRS Meteorological Monitoring Program, WSRC-TR-93-0106, WSRC (1994)

Weber, A. H., Comparison of Savannah River Site's Meteorological Databases, WSRC-RP-93-269, WSRC (1993) 
Table 1. Means and Extremes of SRS Meteorological Data for 1996

\begin{tabular}{|c|c|c|c|c|c|c|c|c|c|c|c|c|c|c|c|c|c|c|c|}
\hline \multirow{3}{*}{ 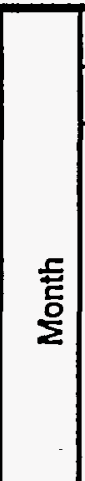 } & \multicolumn{12}{|c|}{ Temperatures $\left({ }^{\circ} \mathrm{F}\right)$} & \multicolumn{7}{|c|}{ Precipitation (in) } \\
\hline & \multicolumn{4}{|c|}{ Average } & \multicolumn{4}{|c|}{ Extremes } & \multicolumn{4}{|c|}{ Number of Days } & \multirow[b]{2}{*}{ 画 } & \multirow[b]{2}{*}{ 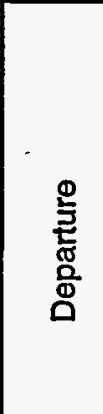 } & \multirow[b]{2}{*}{ 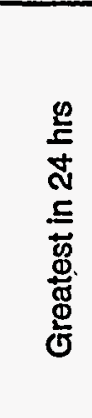 } & \multirow[b]{2}{*}{$\underset{\mathbb{\sigma}}{\mathbf{g}}$} & \multicolumn{3}{|c|}{ No. of Days } \\
\hline & 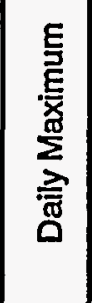 & 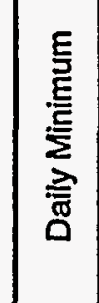 & 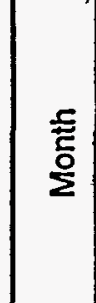 & 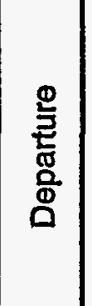 & 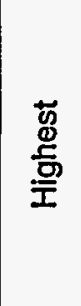 & $\frac{\Phi}{\pi}$ & $\begin{array}{l}\text { 苛 } \\
\text { 言 }\end{array}$ & 獣 & 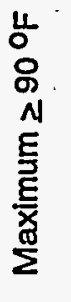 & 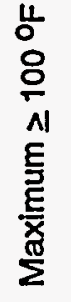 & 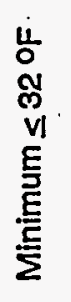 & 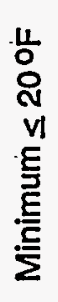 & & & & & $\begin{array}{l}\dot{E} \\
\tilde{\delta} \\
\dot{0} \\
\Lambda\end{array}$ & $\begin{array}{l}\stackrel{\Xi}{\check{D}} \\
\stackrel{0}{N}\end{array}$ & $\begin{array}{l}\dot{\Phi} \\
00 \\
0 \\
N\end{array}$ \\
\hline Jan & 57.0 & 35.4 & 44.6 & -1.2 & 70 & 18th & 21 & 8th & & & 15 & & 3.97 & -0.47 & 1.18 & 27th & 11 & 9 & 2 \\
\hline Feb & 61.3 & 40.7 & 50.1 & +1.0 & 83 & 26 th & 10 & 5 th & & & 9 & 1 & 2.71 & -1.54 & 1.35 & 28 th & 6 & 4. & 2 \\
\hline Mar & 62.4 & 41.1 & 50.6 & -6.4 & $\pi$ & 26th & 19 & 9th & & & 8 & 1 & 7.27 & +2.44 & 1.69 & 7 th & 15 & 9 & 6 \\
\hline Apr & 74.6 & 50.0 & 61.6 & -3.2 & 86 & 20 th & 30 & 10th & $\sim$ & & 1 & & 2.62 & -0.40 & 1.72 & 30 th & 8 & 7 & 1 \\
\hline May & 86.2 & 61.5 & 72.9 & +0.8 & 96 & 19 th & 40 & 1st & 9 & & & & 3.31 & -0.55 & 0.90 & 25th & 6 & 5 & 4 \\
\hline Jun & 88.1 & 66.5 & 76.5 & -2.3 & 97 & 23rd & 52 & 1st & -8 & & & & 3.36 & -1.17 & 1.01 & 8th & 12 & 8 & 3 \\
\hline Jul & 90.2 & 71.1 & 7.9 .3 & -2.4 & 100 & 2nd & 66 & 13th & 17. & 1 & & & 6.24 & +0.67 & 2.47 & 5 th & 14 & 8 & 4 \\
\hline Aug & 86.0 & 69.2 & 76.0 & -4.3 & 90 & 5 th & 63 & 22nd & 1 & & & & 7.70 & +2.26 & 2.00 & 25th & 15 & 8 & 5 \\
\hline Sep & 83.3 & 64.5 & 72.7 & -2.7 & 90 & 9th & 52 & 14th & 1 & & & & 4.03 & +0.40 & .1 .09 & 10th & 12 & 10 & 2 \\
\hline Oct & 74.0 & 52.2 & 62.1 & -3.5 & 85 & 28th & 34 & 20th & & & & & 2.35 & -1.05 & 1.68 & 8th & 5 & 4 & 1 \\
\hline Nov & 64.8 & 41.3 & 51.6 & -4.6 & 79 & ist & 28 & 29 th & & $\therefore$ & 10 & & 1.65 & -1.24 & 0.95 & 8th & 6. & 4 & 1 \\
\hline Dec & 61.3 & 38.8 & 48.8 & -0.3 & 77 & 31st & 18 & 21st & & & 11 & 1 & 3.49 & -0.10 & 1.26 & Ist & 11 & 7 & 3 \\
\hline Year & 74.2 & 52.8 & 62.2 & -2.5 & 100 & $7 / 2$ & 10 & $2 / 5$ & 36 & 1 & 54 & 3 & 48.70 & -0.76 & 2.47 & $7 / 5$ & 121 & 83 & 34 \\
\hline
\end{tabular}


Table 1. Means and Extremes of SRS Meteorological Data for 1996 (cont'd)

\begin{tabular}{|c|c|c|c|c|c|c|c|c|c|c|c|c|c|c|c|c|c|c|c|c|}
\hline \multirow[b]{2}{*}{ 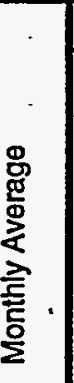 } & \multicolumn{4}{|c|}{ Wind Speed (mph) } & \multicolumn{5}{|c|}{ Barometric Pressure (mb) } & \multicolumn{6}{|c|}{ Solar Radiation (ly) } & \multicolumn{5}{|c|}{ Relative Humidity (\%) } \\
\hline & $\begin{array}{l}\text { 营 } \\
\text { 至 }\end{array}$ & 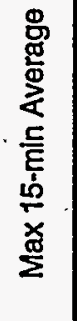 & 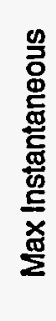 & 惫 & $\begin{array}{l}\stackrel{8}{\mathbb{\Xi}} \\
\stackrel{\mathbb{\Phi}}{\mathbf{D}}\end{array}$ & $\begin{array}{l}\text { 忽 } \\
\text { 亏े }\end{array}$ & هَّ. & $\begin{array}{l}\text { 怘 } \\
\text { 동 }\end{array}$ & 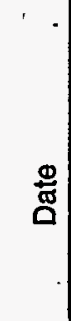 & 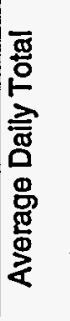 & 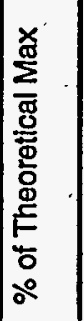 & 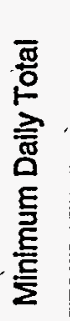 & 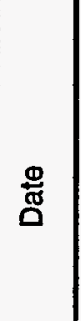 & 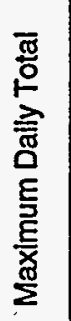 & $\frac{\mathscr{0}}{\tilde{\sigma}}$ & 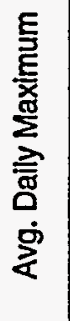 & 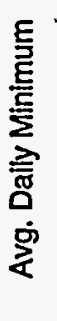 & 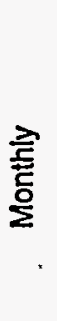 & & 兽 \\
\hline Jan & .2 & 1.5 & 2 & th & .9 & 37 & 2nd & 20 & th & 23 & 0.52 & 23 & 7 th & 349 & 20th & 86 & 49 & 70 & 23 & \\
\hline Feb & 7.6 & 5.9 & 45 & 12th & 1003.2 & 992 & 15th & 1015 & 7 th & 288 & 0.59 & 53 & 2nd & 445 & 10 th & 82 & 43 & 64 & 21 & \\
\hline Mar & 7.7 & 26.6 & 47 & 19th & 1006.2 & 983. & 19th & 1028 & 10th & 348 & 0.58 & 53 & 17th & 602 & $23 \mathrm{rd}$ & 82 & 40 & 62 & 14 & \\
\hline Apr & 7.0 & 23.1 & 43 & 20th & 204.8 & 995 & 1st & 1013 & $22 n d$ & 525 & 0.76 & 57 & 6 th & 694 & 25th & 80 & 31 & 57 & 17 & $P A+$ \\
\hline May & 5.8 & 23.2 & 39 & 27 th & 04.7 & 987 & 28th & 1015. & 15th & 575 & 0.75 & 219 & 13th & 716 & 12th & 85 & 39 & 63 & 26 & \\
\hline Jun & 4.9 & 17.9 & 39 & 8th & 1005.5 & 997 & 10th & 1016 & 1st & 560 & & 379 & 19th & 686 & 27th & 92 & 44 & 71 & 31 & 28 \\
\hline Jul & 6.2 & 22.7 & 50 & 15th & 1004.8 & 992 & 3rd & 1014 & 17th & 483 & 0.62 & 82 & 5th & 670 & 4th & 92 & 49 & 74 & 28 & th \\
\hline Aug & 4.3 & 22.6 & 33 & 8th & 1006.9 & 999 & 12th & 1014 & 20th & .429 & 0.60 & 250 & 9th & 555 & $21 s t$ & 96 & 57 & 81. & 41 & 21 \\
\hline Sep & 5.3 & 17,7 & 39 & 28 th & 1002.9 & 995 & 13th & 1014 & 30th & 406 & 0.66 & 56 & 30th & 566 & 14th & 96 & 51 & 78 & 31 & $13 \mathrm{t}$ \\
\hline Oct & 5.5 & 19.8 & 35 & 8th & 1007.1 & 981 & 8 th & 1018 & 27th & 334 & 0.65 & 45 & 7 th & 468 & 12th & 94 & 49 & 75 & 26 & $24 t$ \\
\hline Nov & 5.9. & 20.2 & 34 & $26 \mathrm{th}$ & 1011.5 & 995 & $21 \mathrm{st}$ & 1026 & 15th & 260 & 0.63 & 94 & 30th & 393 & $3 \mathrm{rd}$ & 87 & 43 & 67 & 25 & 31 \\
\hline Dec & 5.4 & 24.1 & 49 & 13th & 1009.6 & 993 & 7th & 1023 & 21st & 23. & 0.63 & 24 & 1st & 315 & 2nd & 88 & 4 & 70 & 25 & Un \\
\hline & 6.1 & .6 & 50 & 15 & 1006.1 & 1 & 18 & 1028 & $3 / 10$ & 388 & 0.65 & 3 & $1 / 7$ & 6 & & 18 & 45 & 69 & 74 & $3 / 7$ \\
\hline
\end{tabular}


Table 2. Monthly and Annual Average and Extreme Temperatures, 1967-96

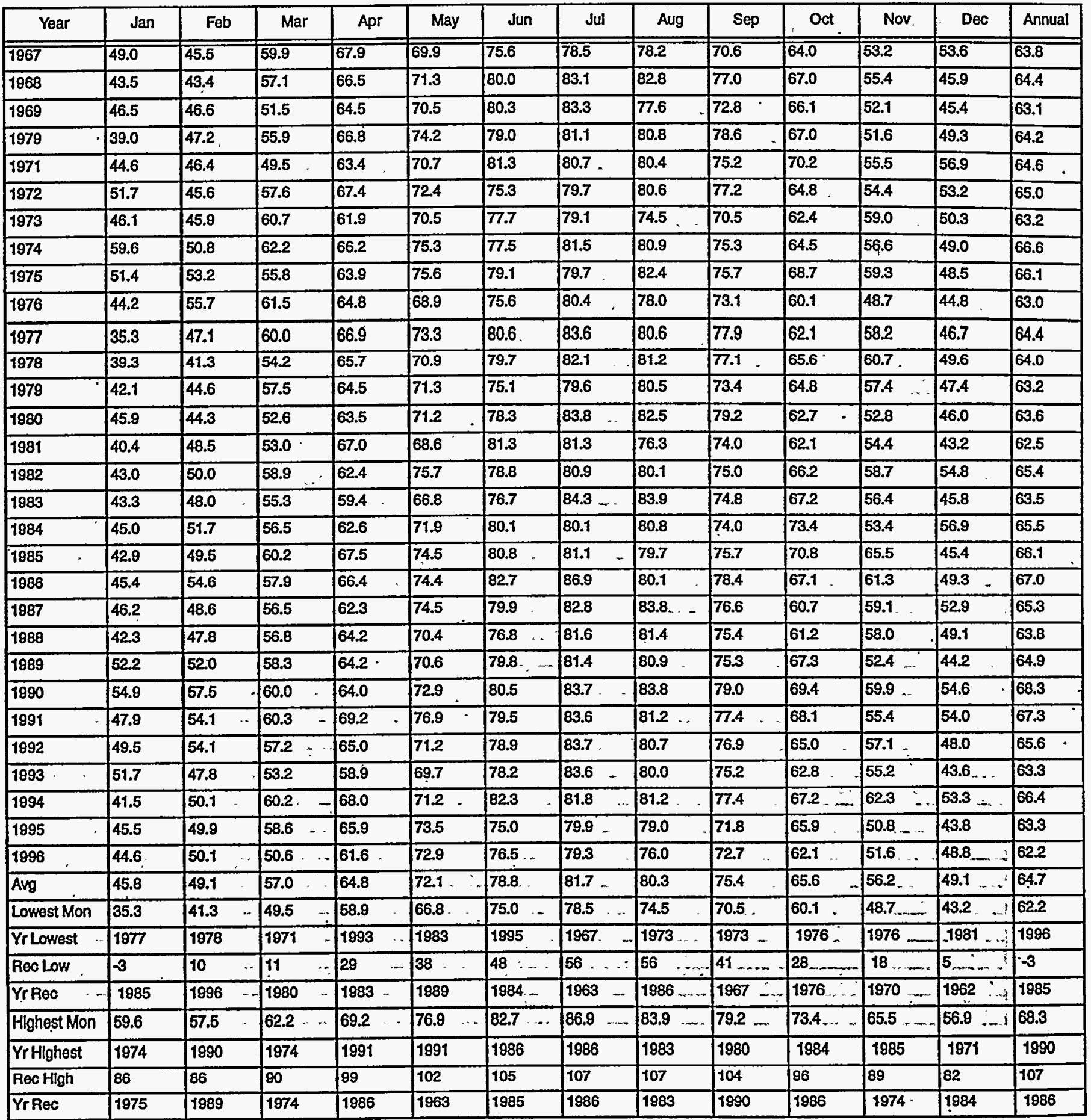


Table 3. Monthly and Annual Rainfall, 1967-96

\begin{tabular}{|c|c|c|c|c|c|c|c|c|c|c|c|c|c|}
\hline Year & Jan & Feb & Mar & Apr & May & Jun & Jul & Aug & Sep ' & Oct & Nov & Dec & Year \\
\hline 1967 & 3.66 & 3.80 & 5.68 & 2.82 & 5.01 & 3.74 & 7.52 & 7.32 & 1.70 & $\overline{0.64}$ & 2.51 & $\overline{3.13}$ & $4 \overline{47.53}$ \\
\hline 1968 & 3.98 & 0.94 & 1.49 & 2.12 & 3.46 & 6.20 & 3.88 & 4.27 & 2.24 & 3.00 & 3.39 & 2.73 & 37.70 \\
\hline 1969 & 2.00 & 2.46 & 3.38 & 4.09 & 3.02 & 3.95 & 2.71 & 5.42 & 4.56 & 1.16 & 0.40 & 4.19 & 37.34 \\
\hline 1970 & 2.79 & 2.69 & 7.36 & 1.38 & 4.16 & 3.46 & 4.85 & 3.79 & 1.71 & 5.01 & 1.68 & 4.92 & 43.80 \\
\hline 197.1 & 5.11 & 4.16 & 8.68 & 2.92 & 2.98 & 5.92 & 10.53 & 8.76 & 3.80 & 5.95 & 2.31 & 2.89 & 64.01 \\
\hline 1972 & 8.91 & 4.42 & 2.82 & 0.57 & 4.72 & 6.57 & 2.64 & 6.05 & 1.47 & 1.20 & 3.56 & 5.23 & 48.16 \\
\hline 1973 & 5.36 & 5.26 & 6.38 & 4.58 & 3.50 & 10.89 & 6.04 & 3.81 & 3.71 & 1.22 & 0.31 & 4.64 & 55.70 \\
\hline 1974 & 2.58 & 7.03 & 2.87 & 2.93 & 4.15 & 2.79 & 4.08 & 6.27 & 3.22 & 0.08 & 2.19 & 3.83 & 42.02 \\
\hline 1975 & 4.98 & 6.64 & 5.91 & 4.42 & 5.15 & $3.84^{\circ}$ & 8.55 & 3.83 & 5.18 & 1.74 & 3.41 & 2.03 & 55.68 \\
\hline 1976 & 4.18 & 1.08 & 3.83 & 2.50 & 10.90 & 4.35 & 1.95 & 1.64 & 5.48 & 4.92 & 4.19 & 5.08 & 50.10 \\
\hline 1977 & 3.72 & 1.62 & 6.86 & 1.27 & 1.79 & \begin{tabular}{|l|}
2.47 \\
\end{tabular} & 3.42 & 7.30 & 5.50 & 4.27 & 1.63 & 3.86 & 43.71 \\
\hline 1978 & 10.02 & 1.32 & 3.07 & 3.53 & 3.64 & 3.43 & 4.12 & 5.11 & 4.06 & 0.06 & 3.54 & 1.88 & 43.78 \\
\hline 1979 & $3: 59$ & 7.74 & 3.09 & 6.49 & 8.94 & 1.54 & 7.85 & 2.12 & 6.13 & 1.35 & 3.95 & 2.17 & 54.96 \\
\hline 1980 & 5.12 & 3.48 & 10.96 & 1.69 & 3.49 & 2.99 & 0.90 & 2.03 & $5.86, \ldots$ & 2.14 & 2.50 & 1.91 & 43.07 \\
\hline 1981 & 0.89 & 5.02 & 4.72 & 2.07 & 6.90 & 4.29 & 3.97 & 5.79 & 0.54 & 2.81 & 1.00 & 9.55 & 47.55 \\
\hline 1982 & 3.94 & 4.45 & 2.50 & 5.68 & 2.72 & 4.27 & 11.48 & 5.00 & 4.62 & 3.87 & 2.40 & 4.83 & 55.76 \\
\hline 1983 & 3.77 & 7.21 & 6.77 & 5.77 & 1.67 & 6.57 & 4.85 & 6.32 & $3.56 \ldots$ & $1.92 \ldots$ & 5.38 . & 4.15 . & 57.94 \\
\hline 1884 & 3.51 & $7.09-$ & 6.05 & 8.00 & 9.79 & 2.54 & 7.28 & 5.52 & 0.60 & $0.31 \ldots$ & 0.90 & 1.38 & 52.97 \\
\hline 1985 & 3.01 & $6.91 \cdots$ & 1.31 & 0.84 & 1.70 & 4.61 & 8.10 & 4.37 & 0.49 & 6.34 & 6.36 & 2.48 & 46.52 \\
\hline 1986 & 1.46 & 3.56 & 4.08 & 1.44 & 3.83 & 3.00 & 2.96 & 10.89 & 1.54 & 4.18 & 5.82 & 5.82 & 48.58 \\
\hline 1987 & 7.39 & $7.55 \cdots$ & $4.97 \ldots$ & 0.69 & 3.57 & 5.64 & 4.86 & 4.92 & 3.55 & 0.29 & 2.74 & 1.41 & 47.58 \\
\hline 1988 & 4.15 & 3.18 & 2.90 & $4.78 \quad-\cdot$ & 2.85 & 7.11 & 1.78 & 6.77 & 4.40 & 3.39 & 2.16 & 2.91 & 46.38 \\
\hline 1989 & 1.42 & 3.59 & 5.52 & 4.89 & 2.60 & 6.67 & $11: 46$ & $3.27-$ & 4.87 & 3.35 & 2.99 & $4.4 i$ & 55.04 \\
\hline 1990 & $3.07 \cdots$ & $2.38:$ & 2.37 & $1.21 \cdots$ & 2.95 & 0.89 & 7.31 & 8.07 & $0.62 \div$ & 19.62 & 3.11 & $1.57 \ldots$ & 53.17 \\
\hline 1991 & 7.03 & 1.84 & 5.44 & 4.73 & 3.06 & 2.17 & 7.89 & 9.26 & 4.40 & 0.99 & 1.55 & $3.32 \ldots$ & 51.68 \\
\hline 1992 & 4.45 & 3.89 & 2.98 & 2.40 & 1.34 & 6.27 & 3.69 & 4.84 & 6.38 & 3.11 & 7.78 & $2.86 \ldots$ & 49.99 \\
\hline 1993 & $7.45=$. & 3.62 & 8.37 & 1.75 & 1.43 & 3.27 & 3.12 & 2.48 & 7.29 & 4.13 & 1.87 & $1.81 \ldots$ & 46.59 \\
\hline 1994 & 4.80 & $3.91 \ldots$ & $6.42 \cdots$ & 1.04 & 1.45 & 5.08 & 7.47 & 3.47 & 1.67 & 10.01 & 3.05 & $4.62-$ & 52.99 \\
\hline 1995 & 6.95 & 7.97 & $0.91 \cdots$ & $1.28 \cdots$ & 1.77 & 8.15 & 5.71 & 6.92 & 5.75 & 2.64 & 2.38 & 4.47 & 54.90 \\
\hline $1996 \div$ & $3.97 \cdots$ & 2.71 & 7.27 & 2.62 & 3.31 & $3.36 \cdots$ & $6.24 \cdots$ & 7.70 & 4.03 & 2.35 & 1.65 & 3.49 & 48.70 \\
\hline$\cdots$ & & $\cdots$ & $-2 x-$ & - & & $\cdots ;$ & $\cdots$ & 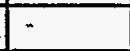 & $\cdot$ & - & & $\ldots \cdot$ & \\
\hline Avg & 4.44 & 4.25 & 4.83 & 3.02 & 3.86 & $4.53 \cdots$ & $5.57-$ & 5.44 & $3.63 \ldots$ & $3.40 \ldots$ & 2.89 & 3.59 & 49.46 \\
\hline Max 7 & $10.02^{-n}$ & 7.97 & 10.96 & $8.20: \cdots$ & 10.90 & 10.89 & $11: 48-$ & 12.34 & $8.71 \div-\cdots$ & 19.62 & 7.78 & 9.55 & .73 .47 \\
\hline YrMax & 1978 & $1995 \therefore$ & 1980 & 1961 & 1976 & $1973-\therefore$ & $1982 \ldots$ & $-1864 \cdots$ & $1959 \ldots$ & 1990 & 1992 & 1881 & 1964 \\
\hline $\operatorname{Min}:$ & $0.89 ; \%$ & $0.94 \ldots$ & $0.91 \%$ & $0.57 ;$ & $1.31 \ldots$ & 0.89 & $0.90 \ldots$ & 1.04 & $0.49 \ldots$ & $0.06 \ldots$ & 0.21 & $0.46 \ldots$ & 28.82 \\
\hline YrMin & $1981 \ldots$ & $1968-=$ & 1995 & 1972 . & $1965 \ldots$ & $1990=$ & $1880 \ldots$ & 1963 & $1985:-$ & $1963 \ldots$ & .1958 & $1955 \ldots$ & 1954 \\
\hline
\end{tabular}


FIGURE 2. 1996 DAILY HIGH AND LOW TEMPERATURES

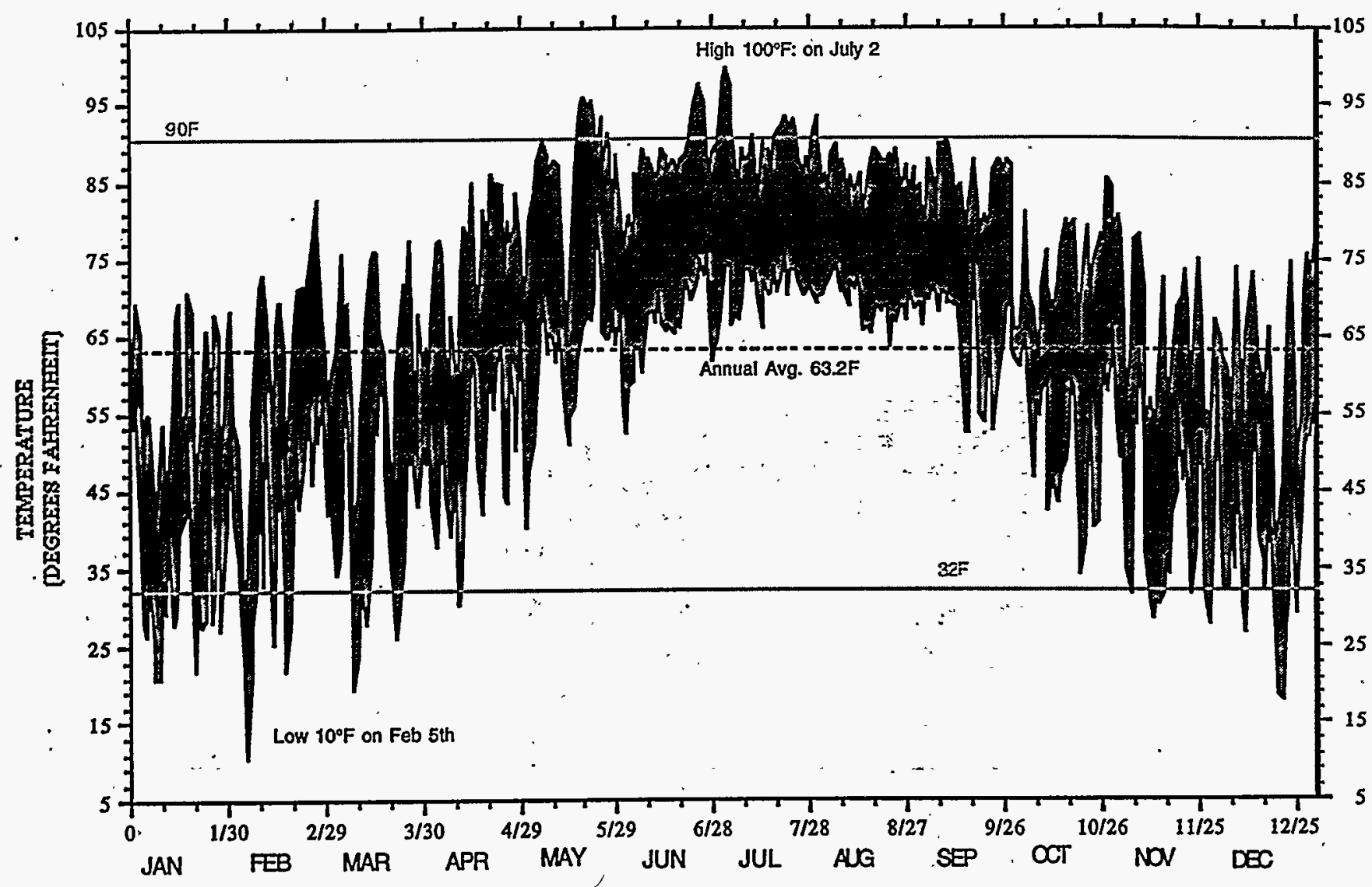

$1, \ldots, \ldots, 0,0$ 
FIGURE 3. SRS ANNUAL AVERAGE TEMPERATURE 1967-1996

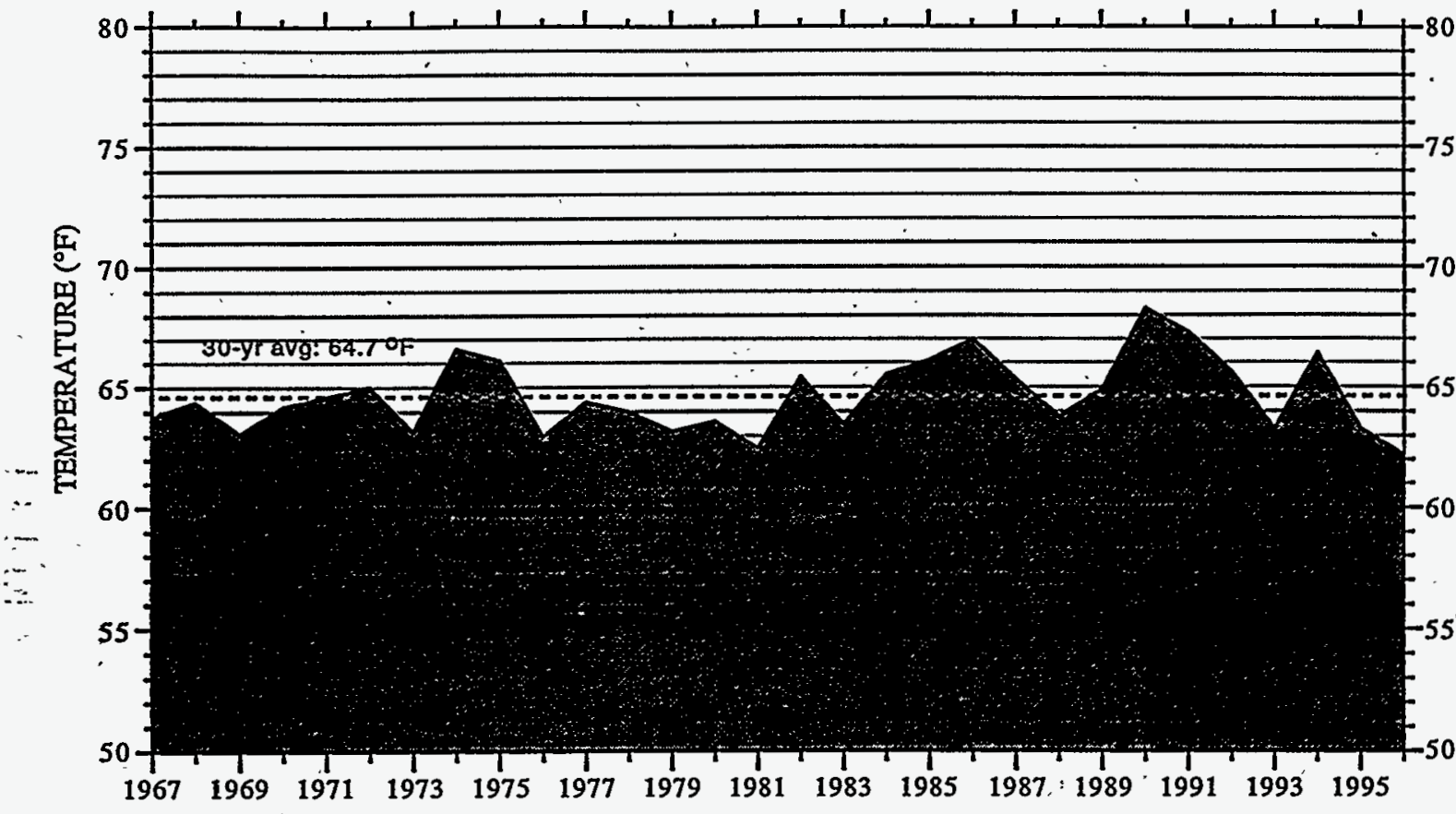

FIGURE 4. SRS MONTHLY AVERAGE TEMPERATURE

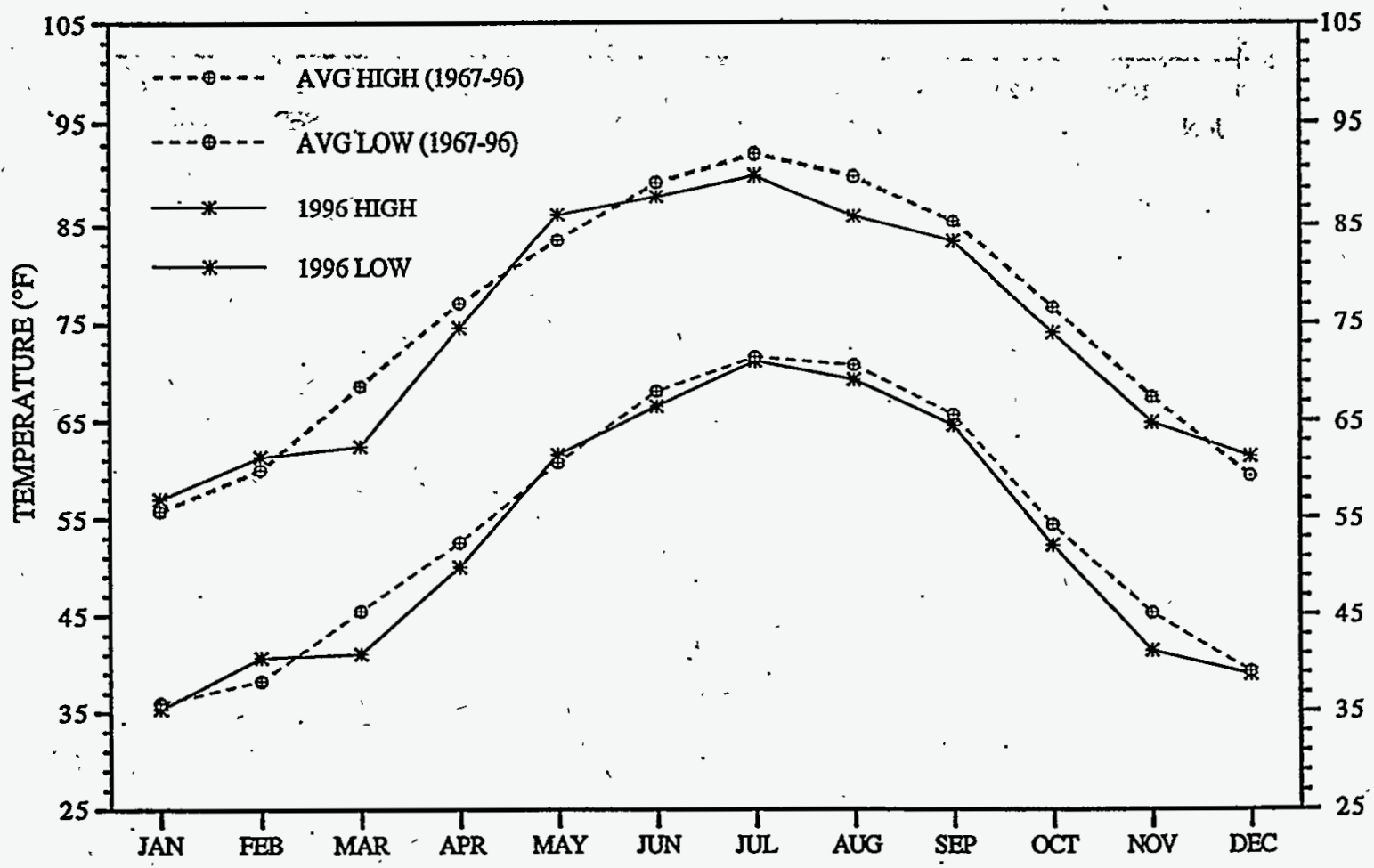


FIGURE 5. NUMBER OF FREEZING $\left(<32^{\circ} \mathrm{F}\right)$ AND SWELTERING ( $\left.>90^{\circ} \mathrm{F}\right)$ DAYS

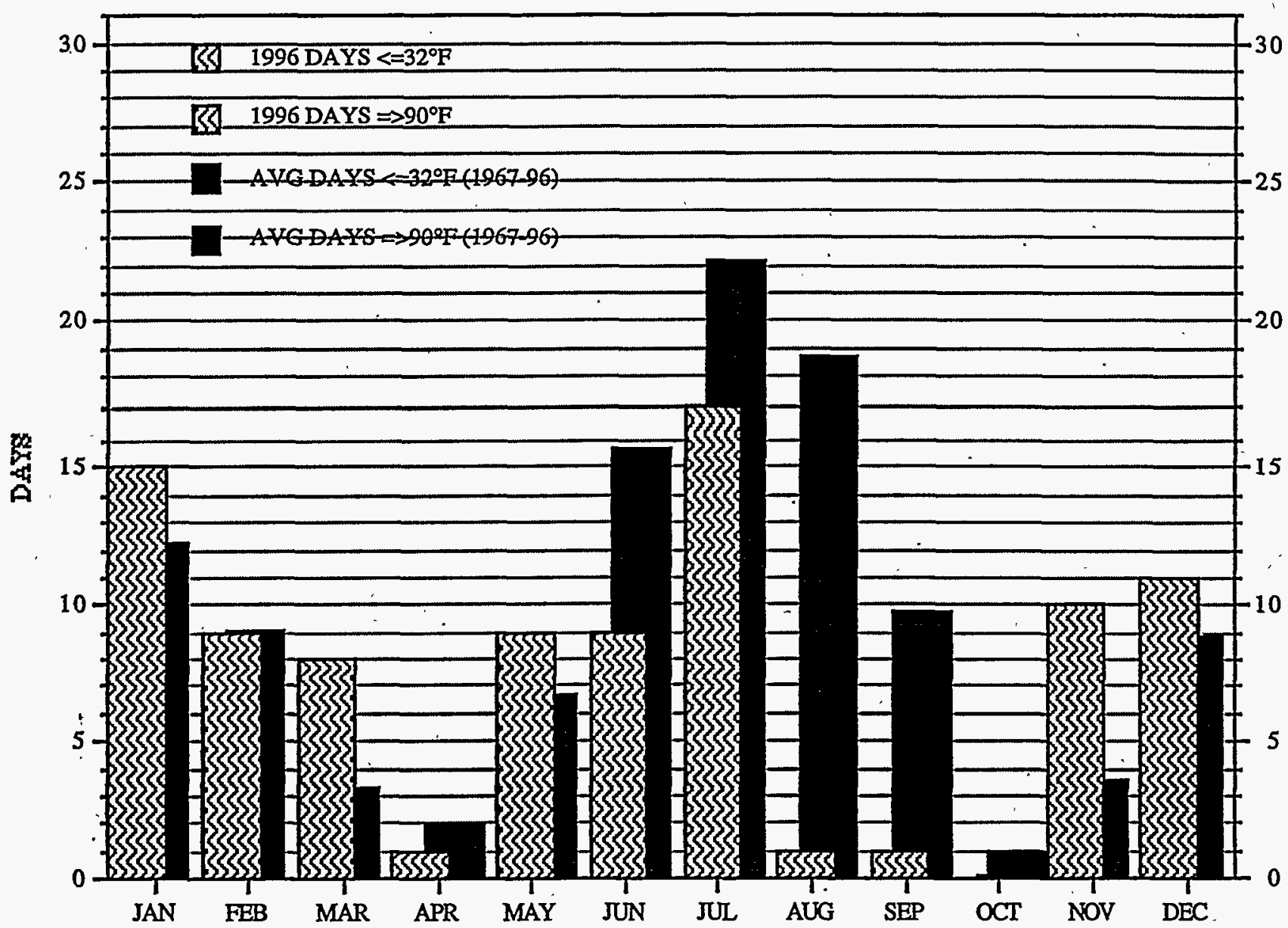


FIGURE 6. 1996 SRTC DAILY PRECIPITATION

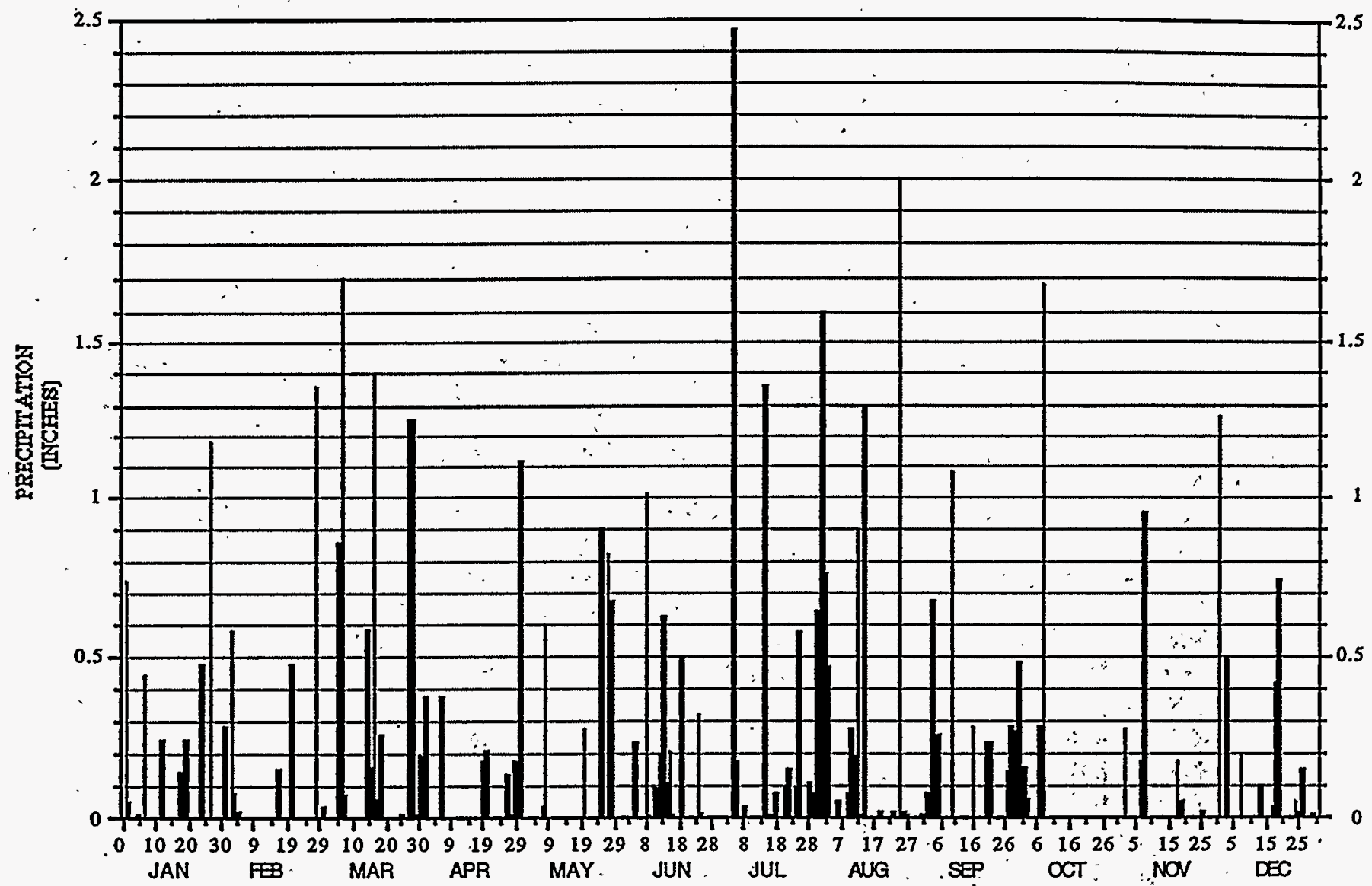

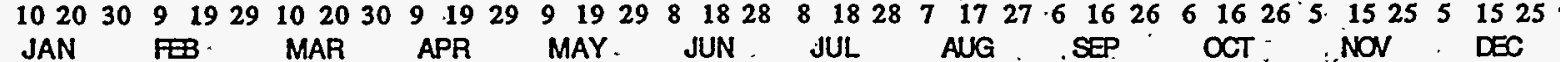




\section{FIGURE 7. SRS ANNUAL PRECIPITATION 1967-1996}

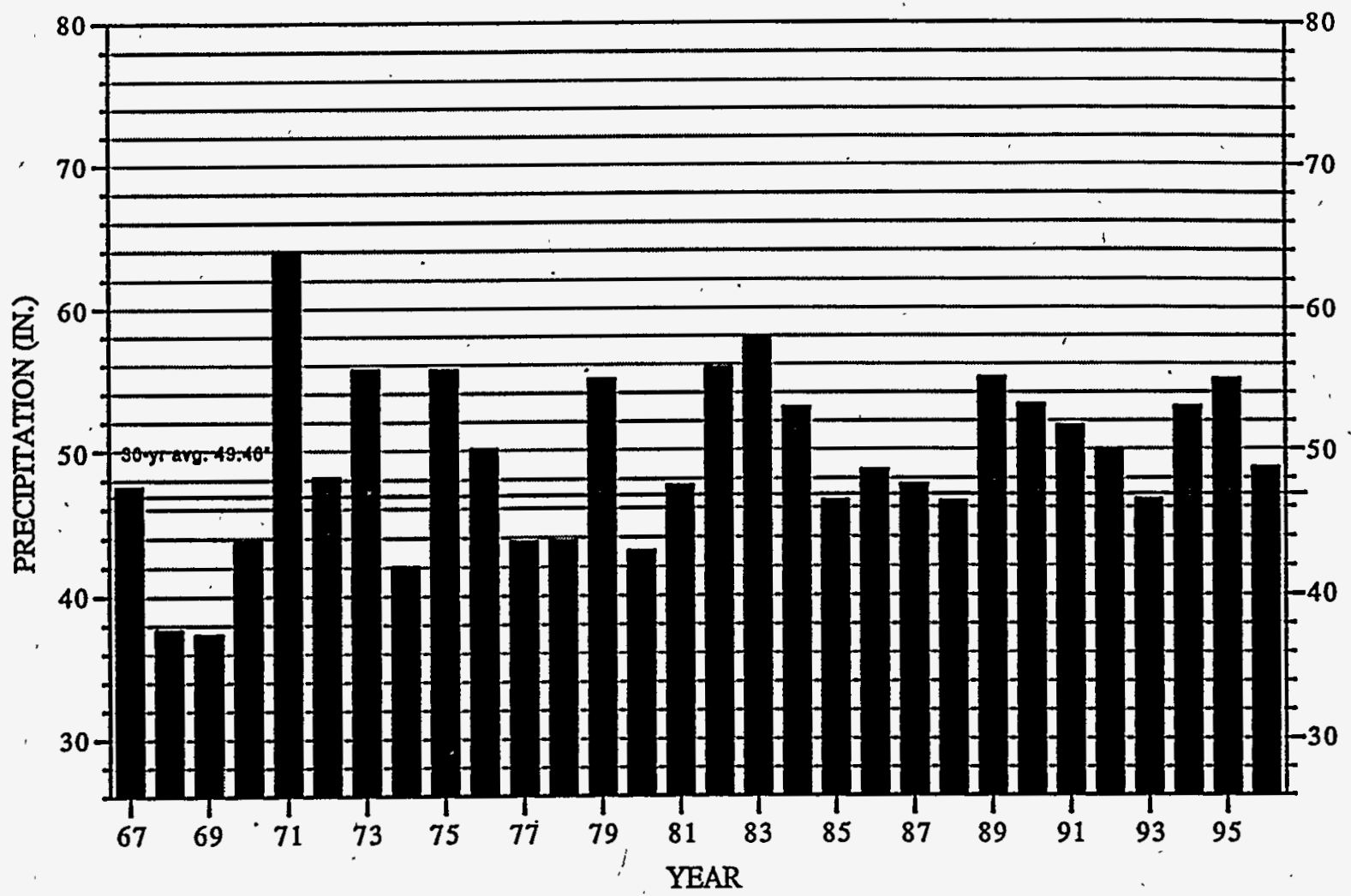

FIGURE 8:- SRS MONTHLY PRECIPITATION

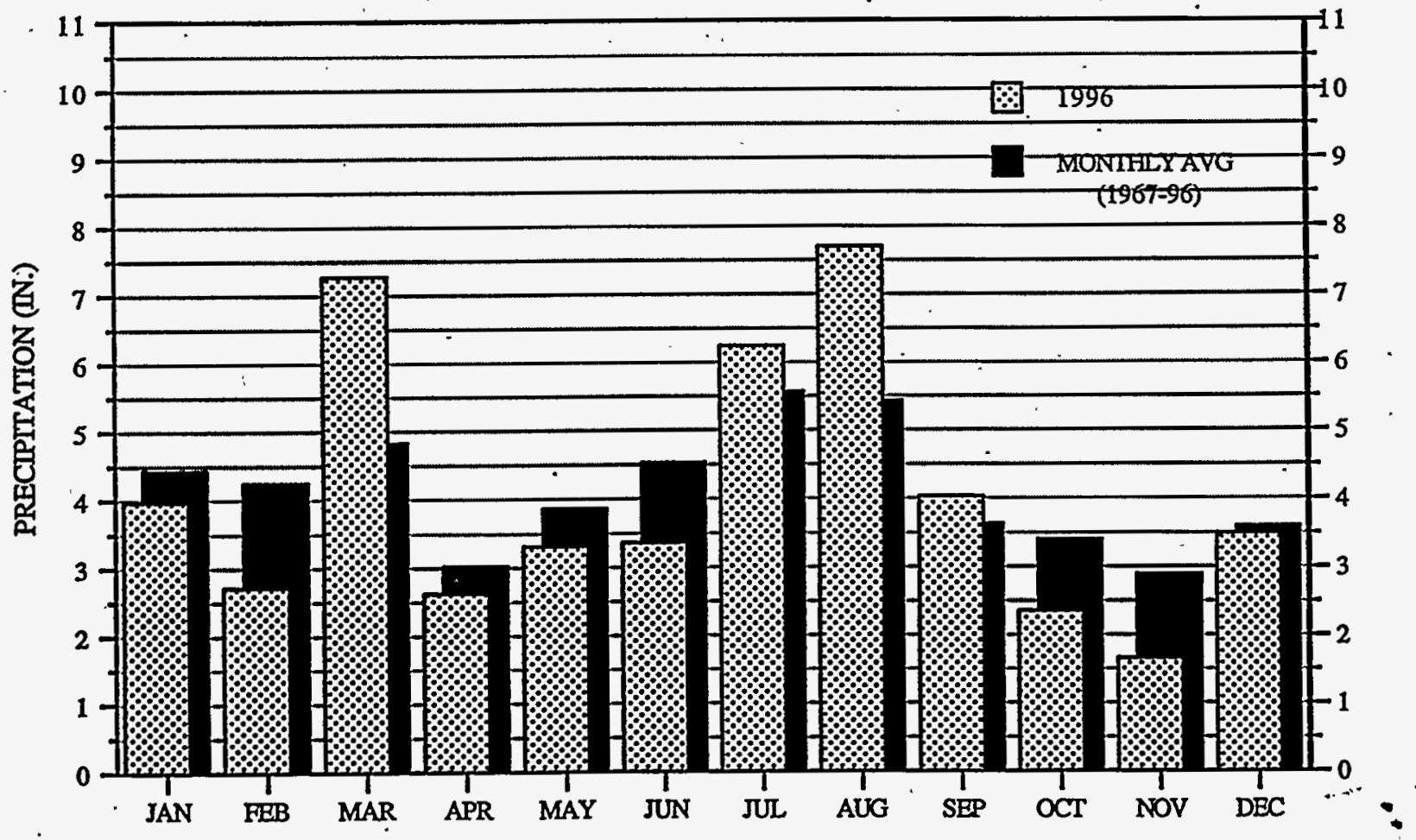




\section{FIGURE 9. 1996 DAIIY HIGH AND LOW HUMIDITY}
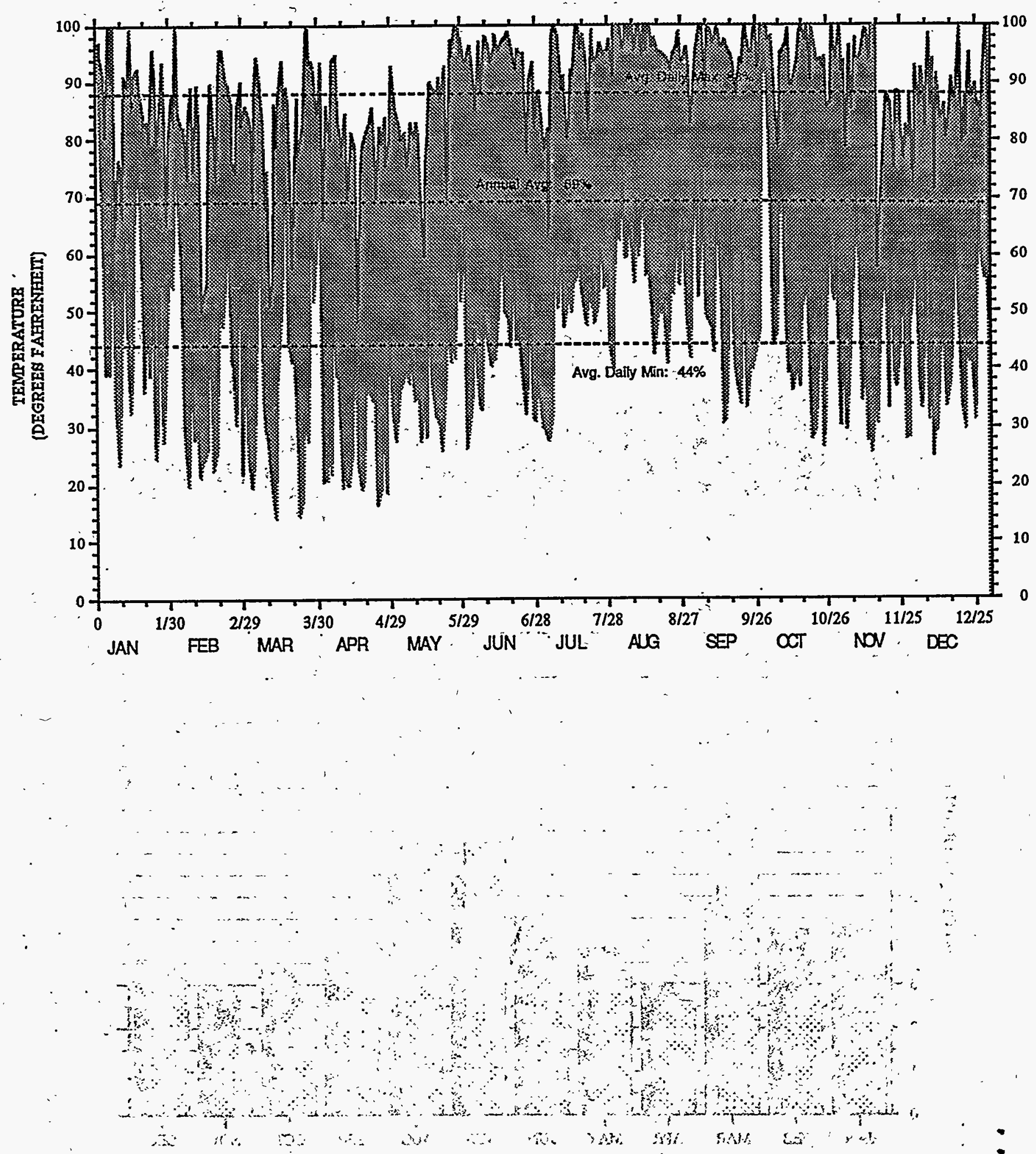
FIGURE 10. SRS ANNUAL AVERAGE HUMIDITY 1967-1996

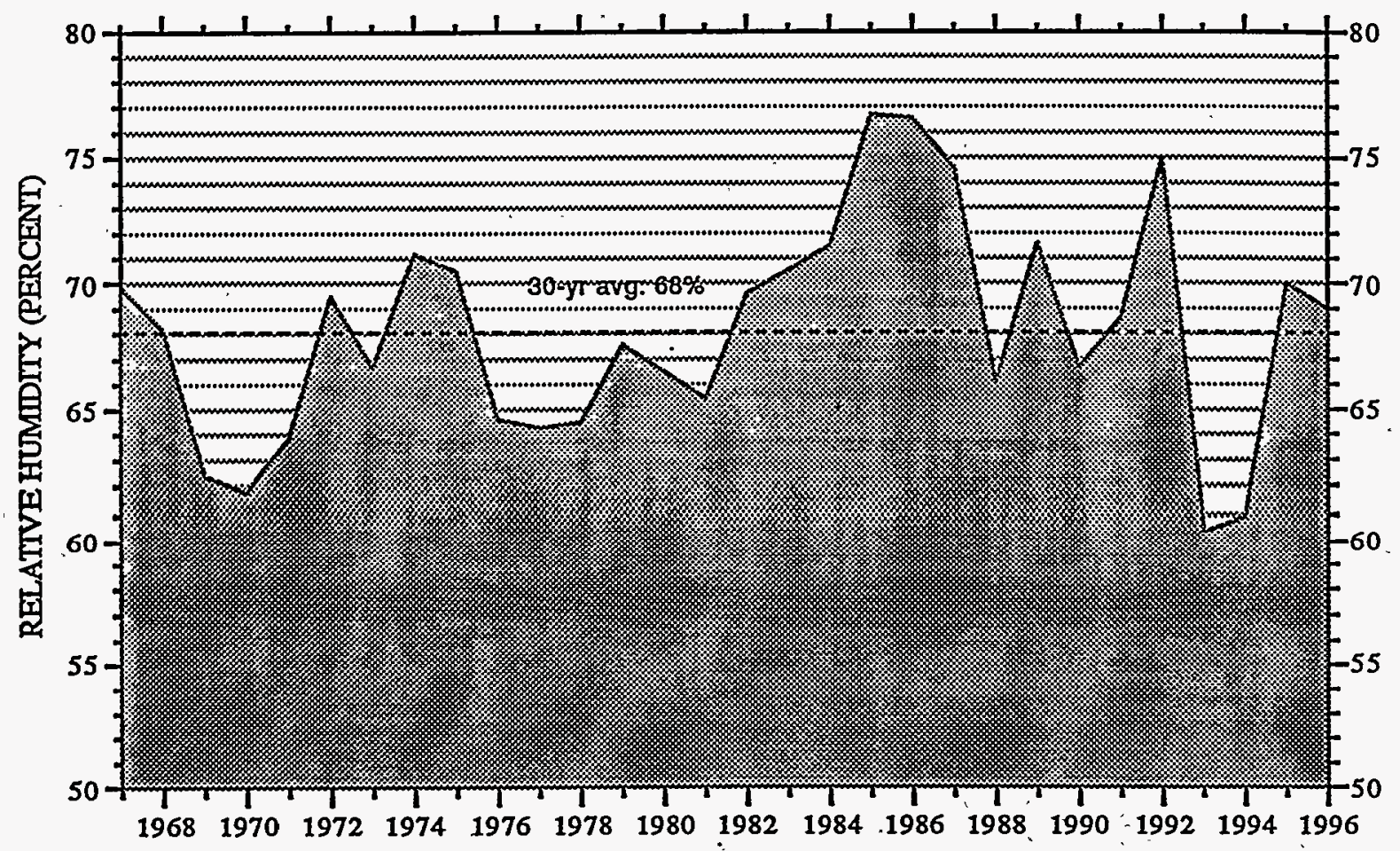

FIGURE 11. SRS MONTHLY AVERAGE MINIMUM HUMIDITY

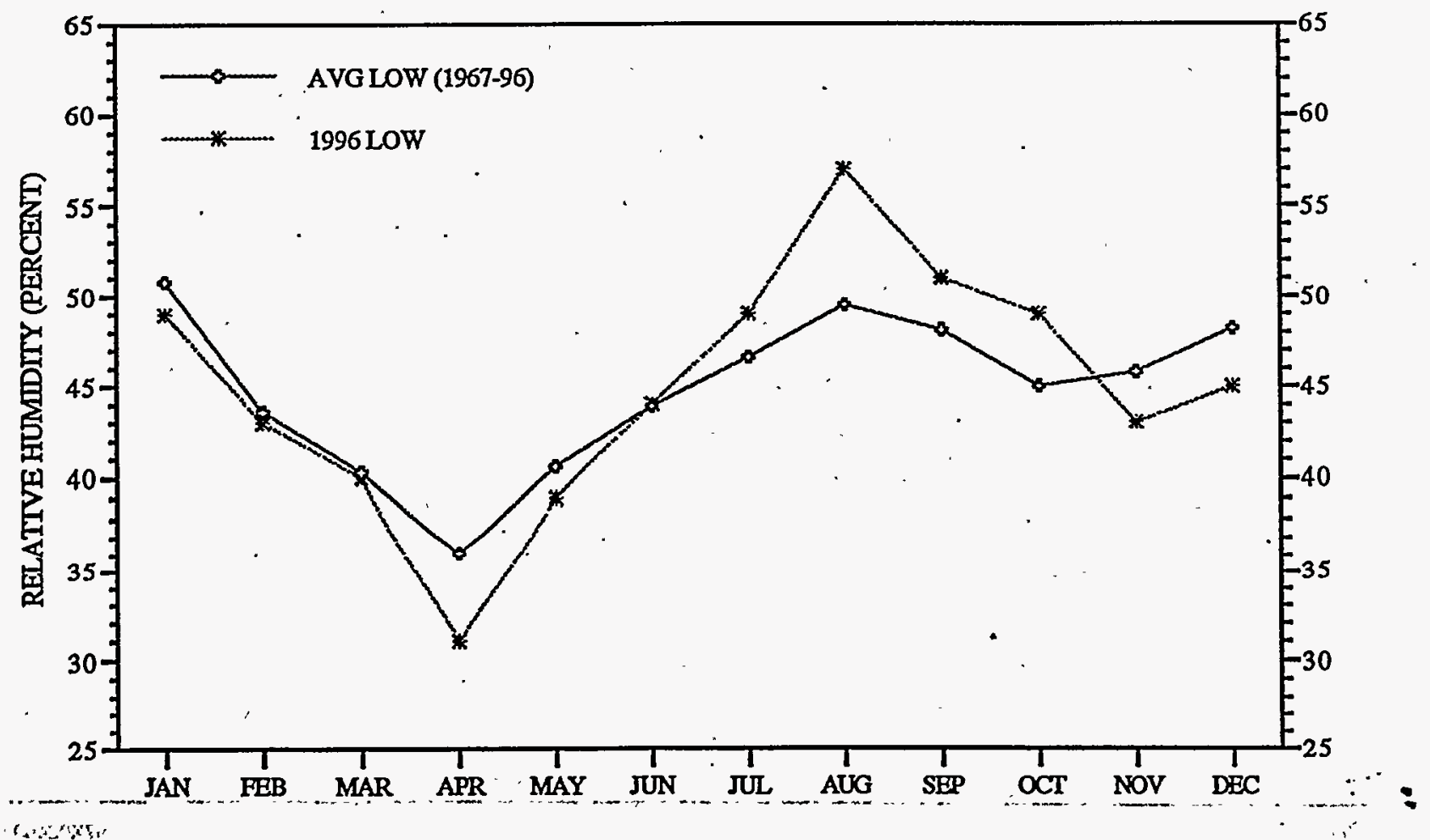


FIGURE 12. 1996 DAILY AVERAGE WIND SPEED

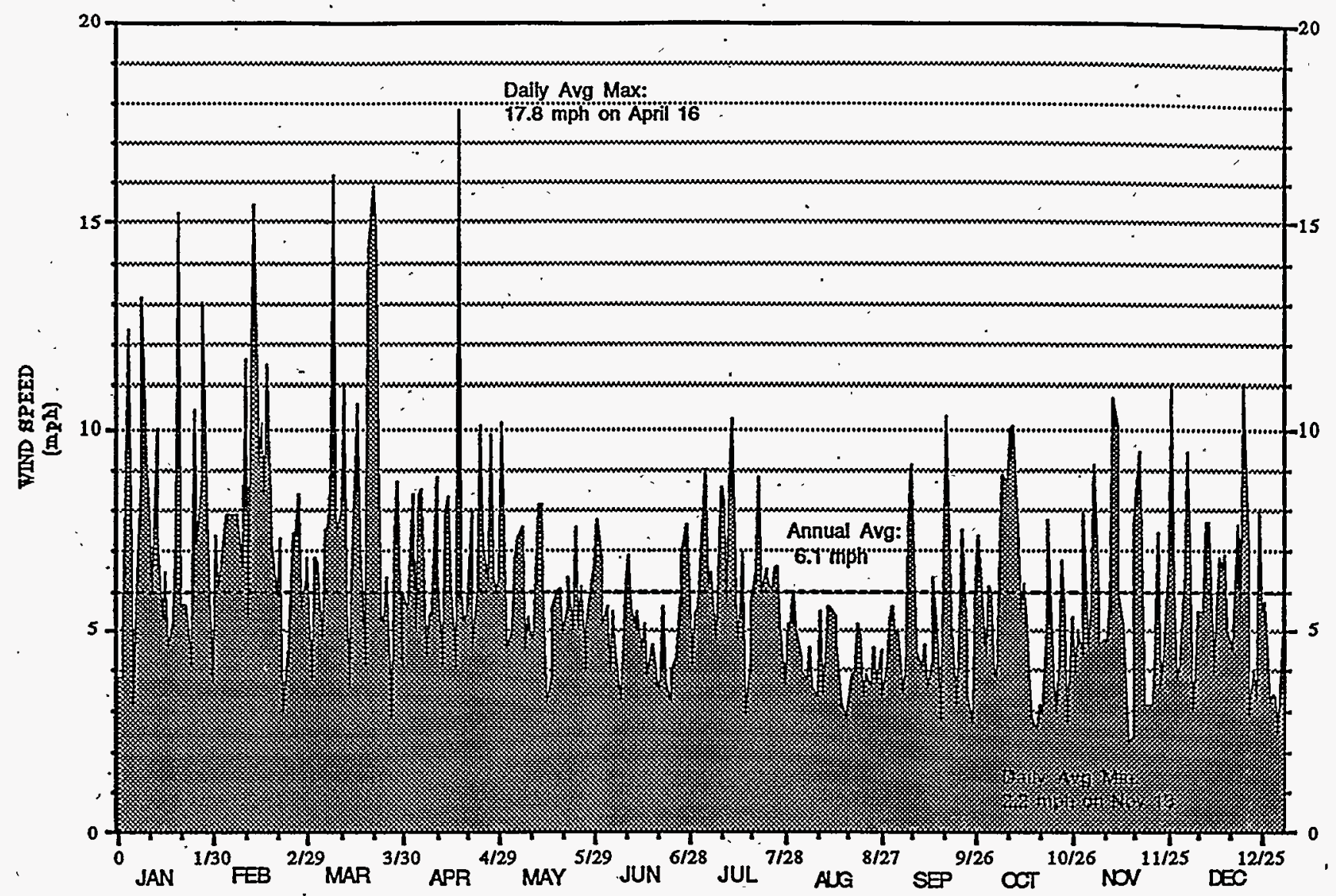




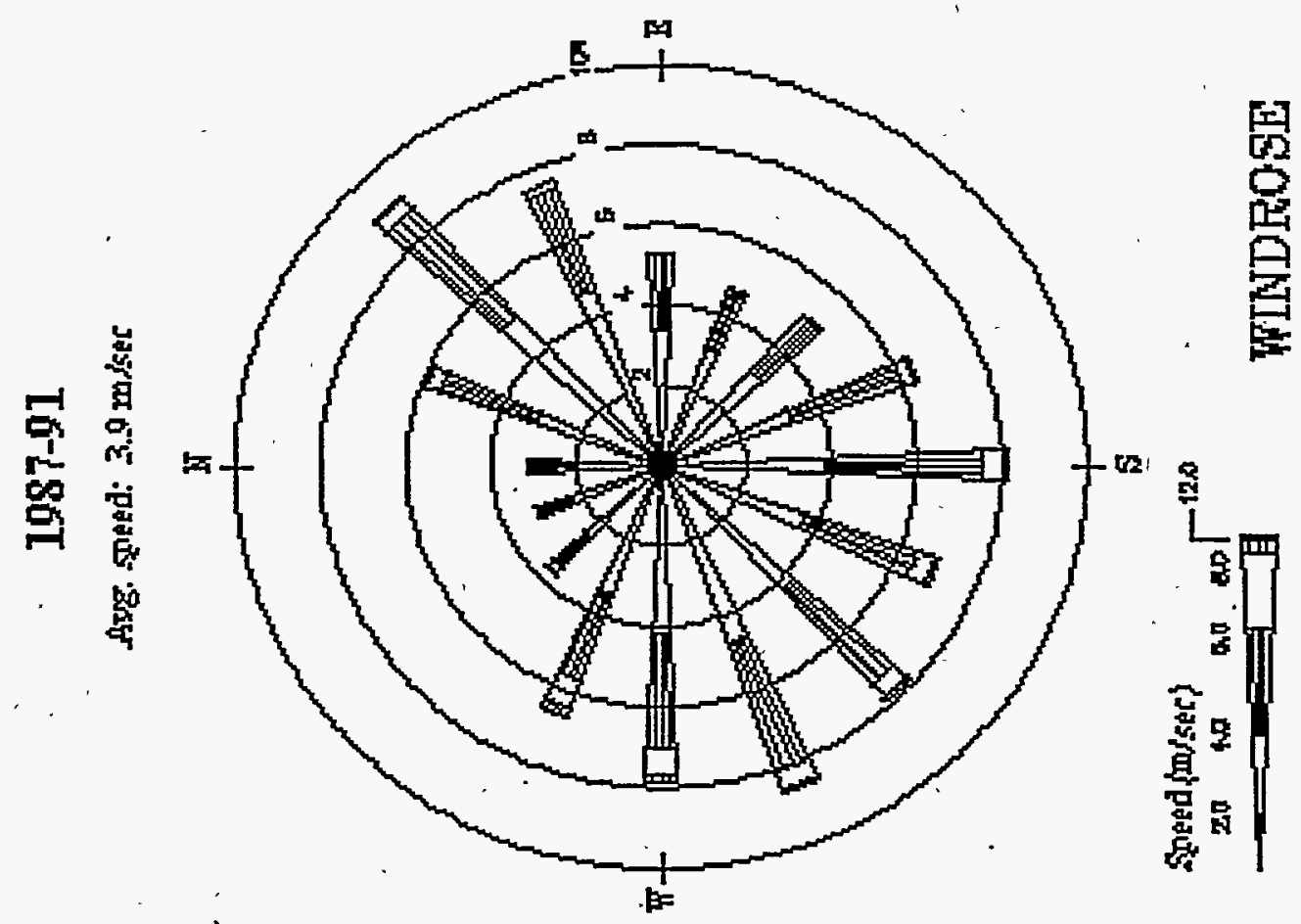

是

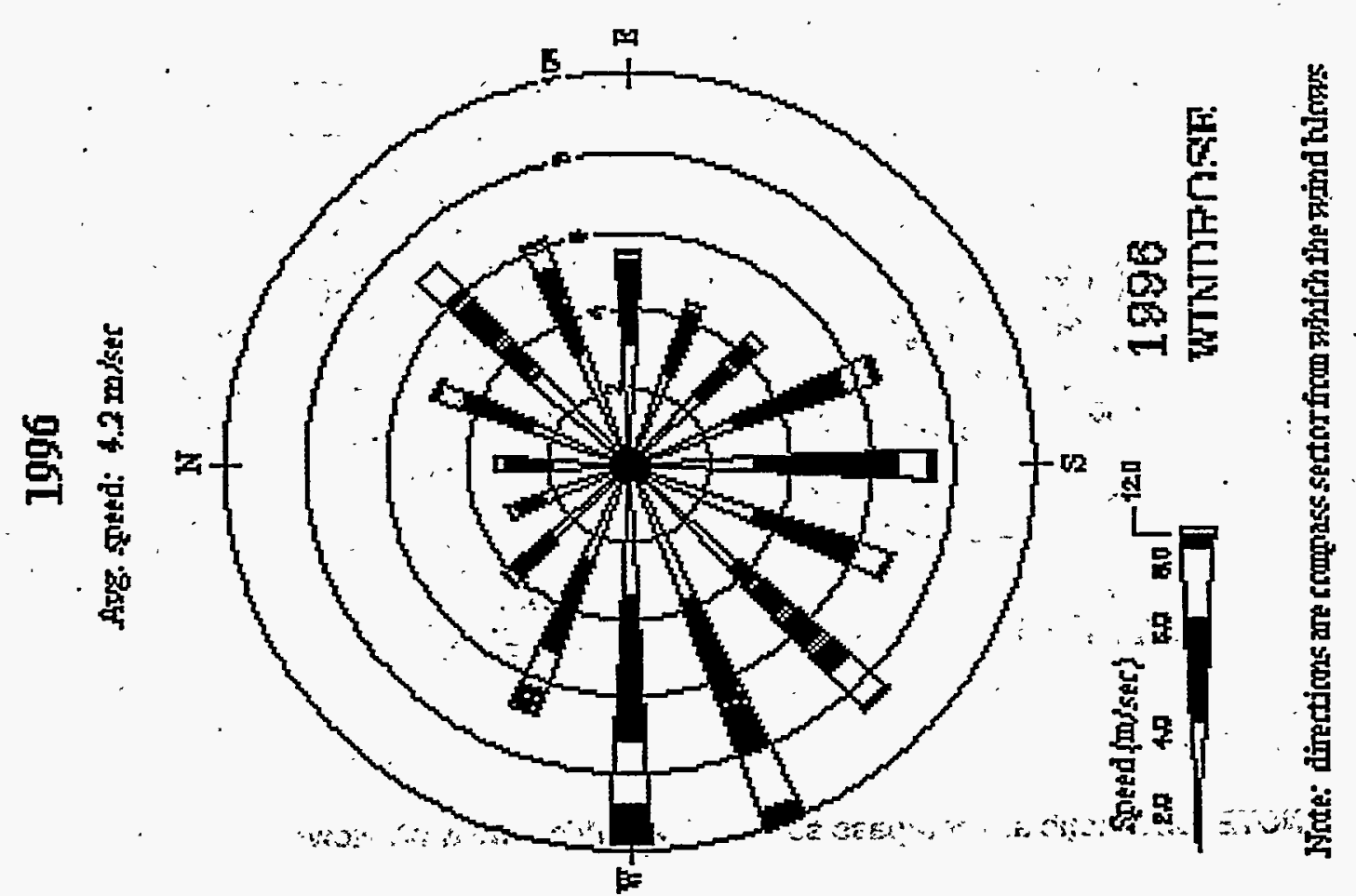



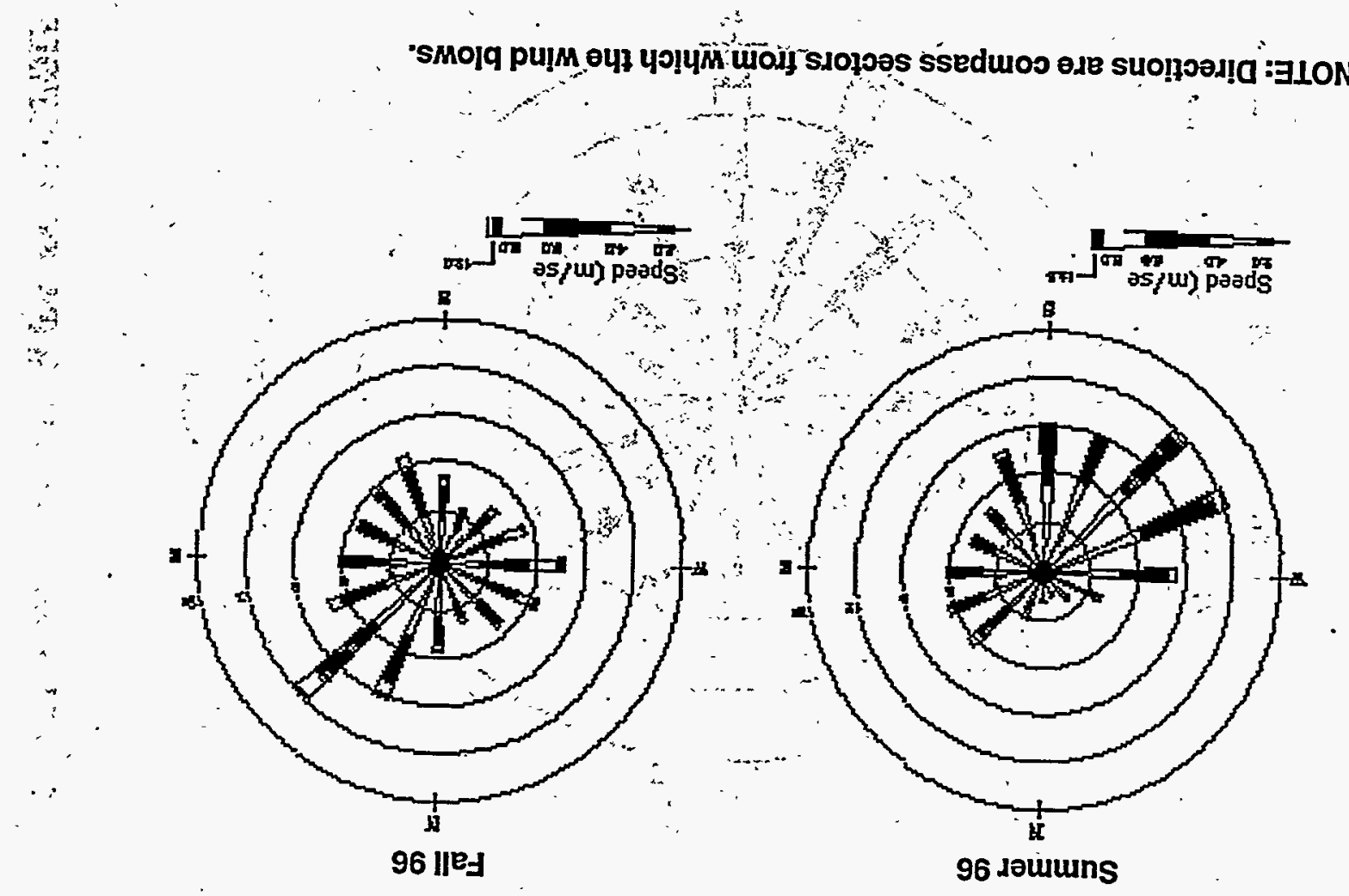

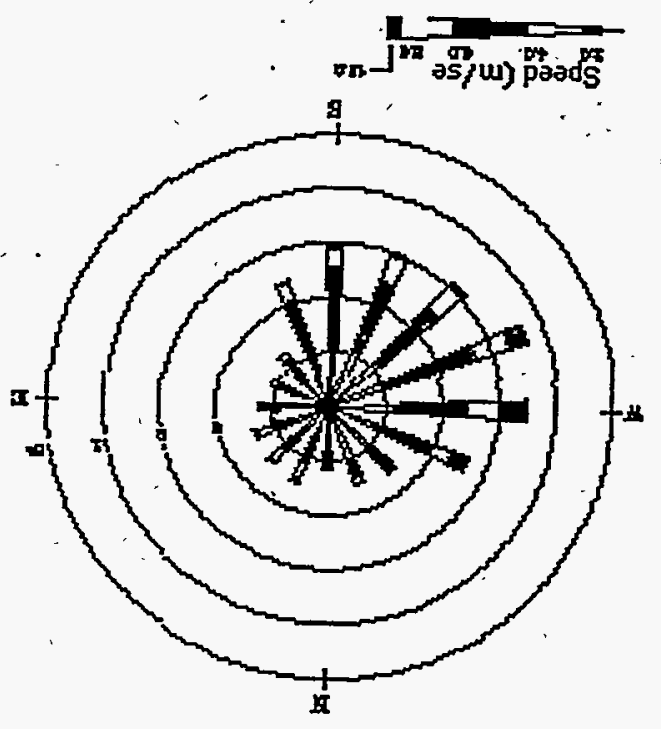

96 bu!lds

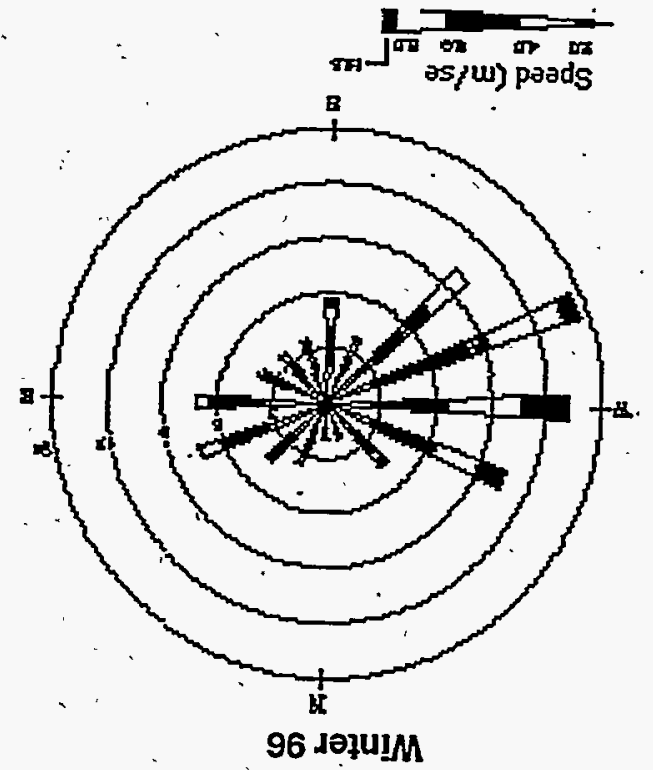

96 มәฺนu $M$ 
FIGURE 15. Seasonal Wind Rose, 1987-91

Winter 87-91

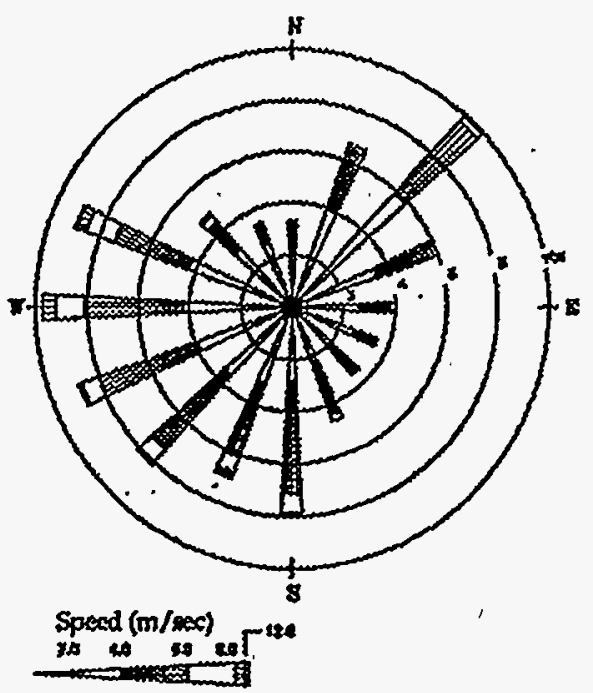

Summet 87-91

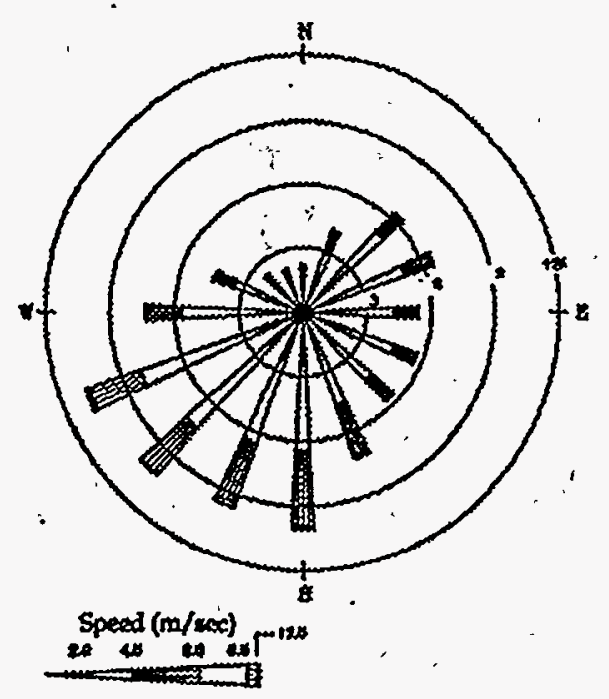

- Note Diredlant are compless sector from which the wind btows.
- Spring 87-91
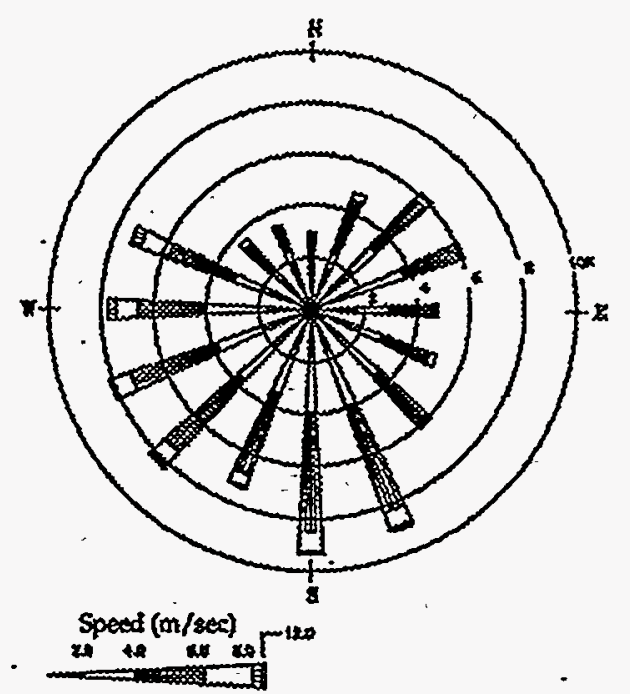

Fall 87-91

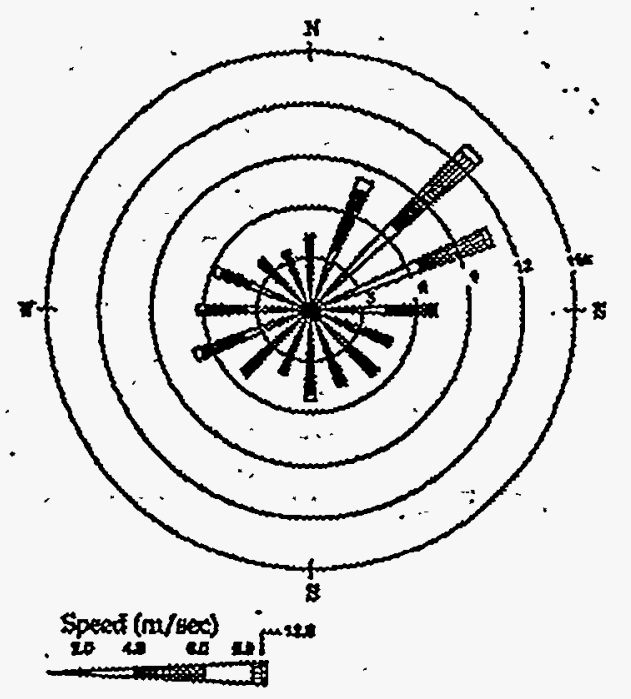


Figure 16. Annual Wind Roses for A, B, D, and F Towers

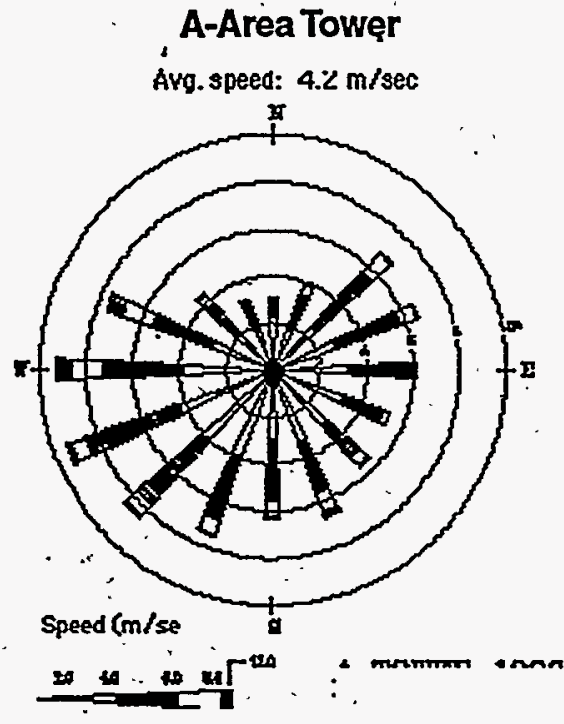

D-Area Tower

Avg. speed: $5.5 \mathrm{~m} / \mathrm{sec}$

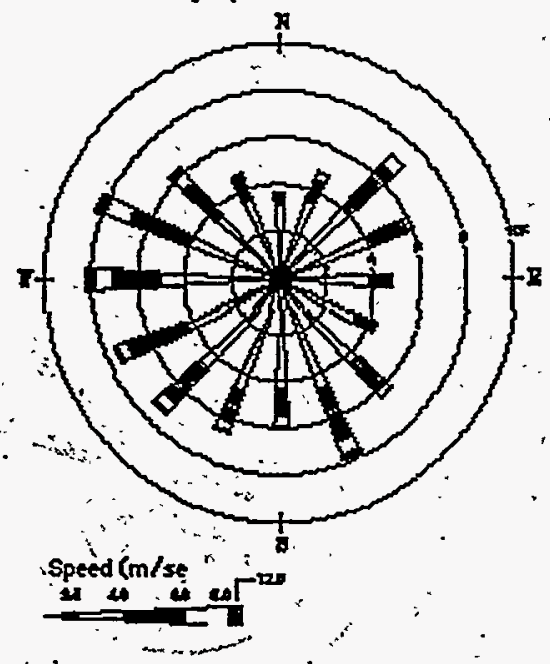

C-Area Tower

Ałg. speed: $4.3 \mathrm{~m} / \mathrm{sec}$
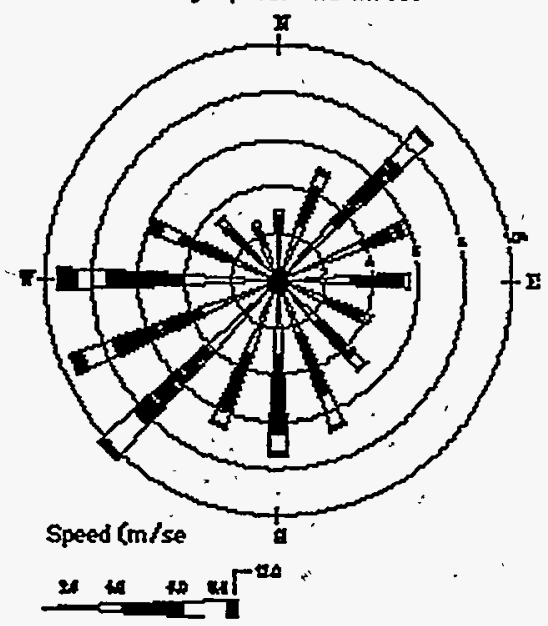

F-Area Tower

Avg. speea: $4.5 \mathrm{~m} / \mathrm{sec}$

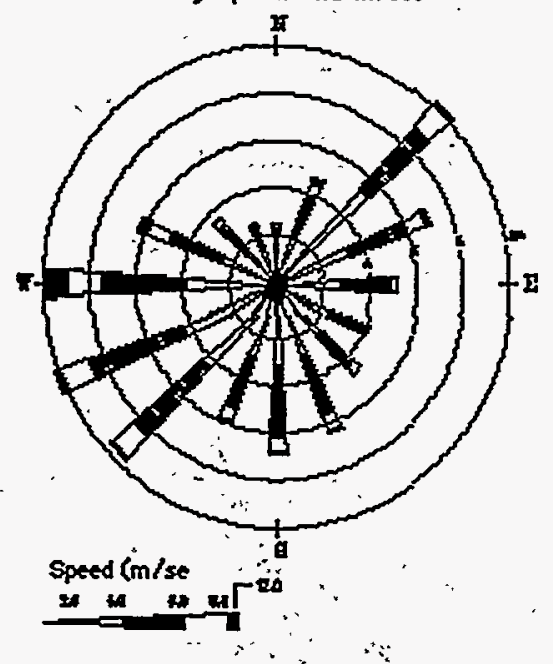

NOTE: Directions are compass sectors from which the wind blows.

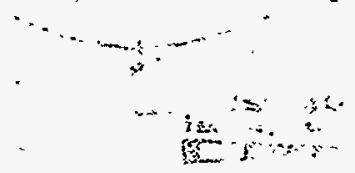


Figure 17. Annual Wind Roses for H, K, L, and P Towers, 1996

H-Area Tower,

Avg. speed: $4.0 \mathrm{~m} / \mathrm{s}$

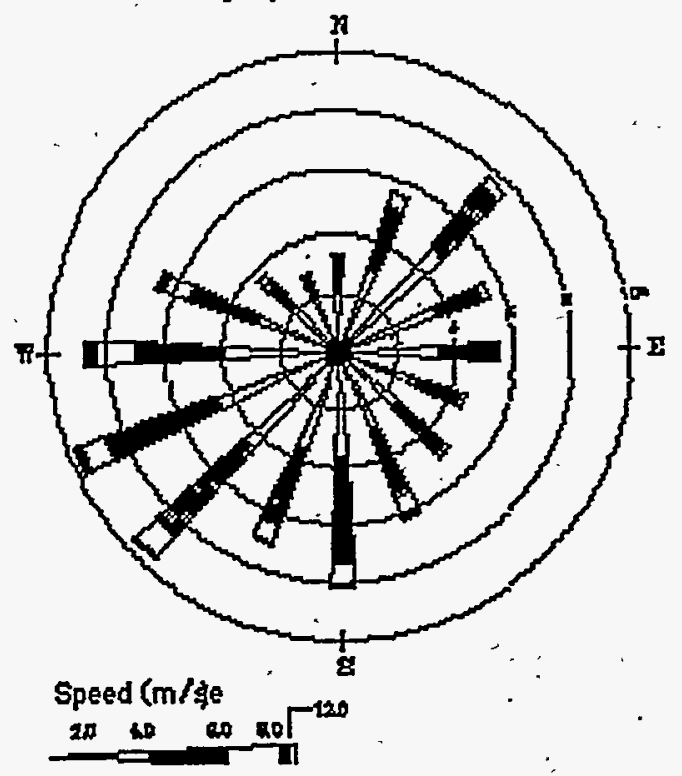

L-Area Tower

Avg. speed: $4.2 \mathrm{~m} / \mathrm{s}$

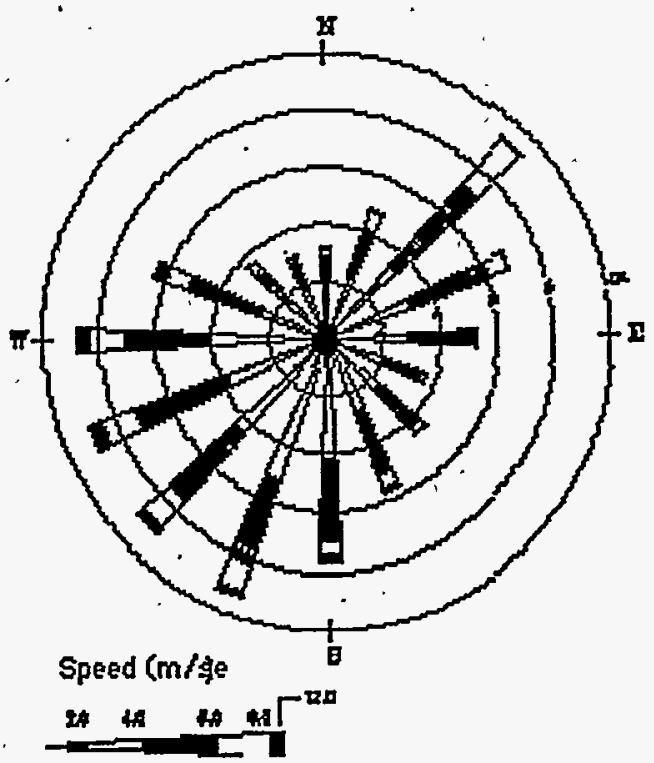

K-Area Tower,

Ayg. speed: $4.2 \mathrm{~m} / \mathrm{s}$

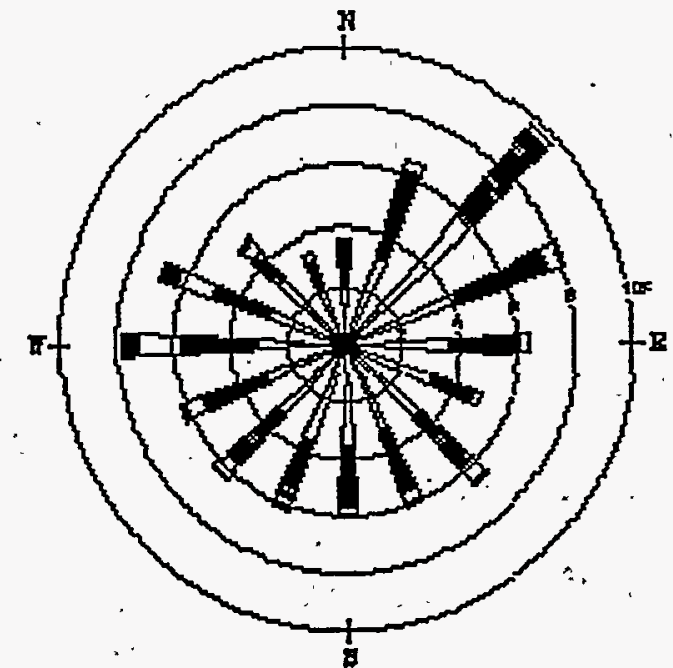

$6 \quad$ Speed $\left(\mathrm{m} / \mathrm{se} \mathrm{NO}^{-120}\right.$

\section{P-Area Tower}

AYg. speed: $4.3 \mathrm{~m} / \mathrm{s}$

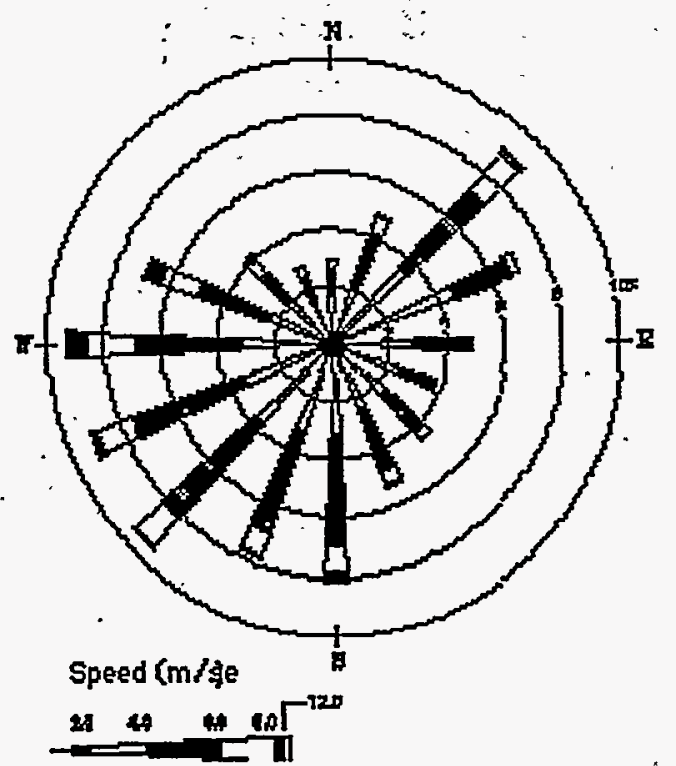


FIGURE 18. 1996 DAILY AVERAGE BAROMETRIC PRESSURE

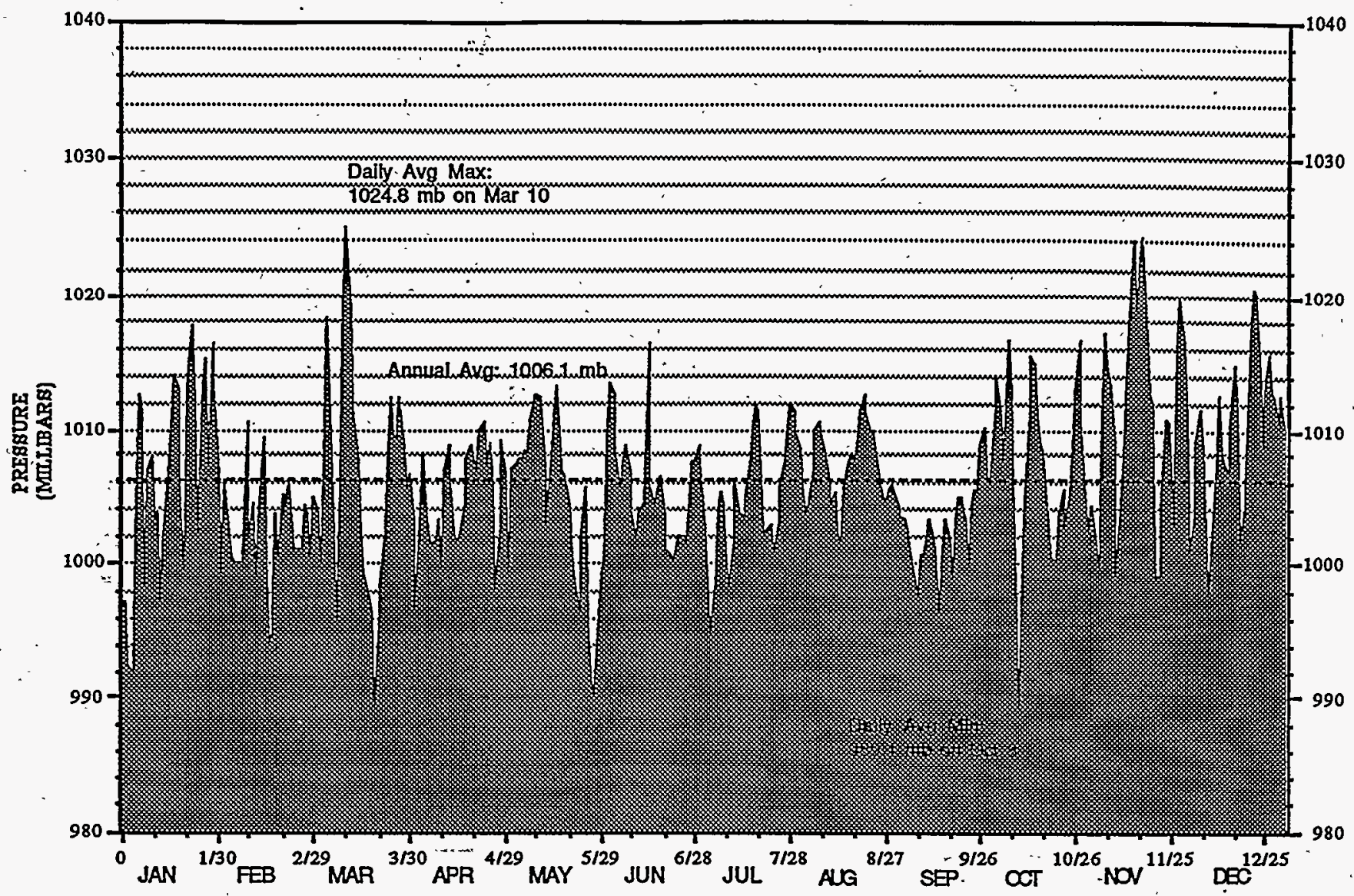


FIGURE 19. 1996 DAILY SOLAR RADIATION

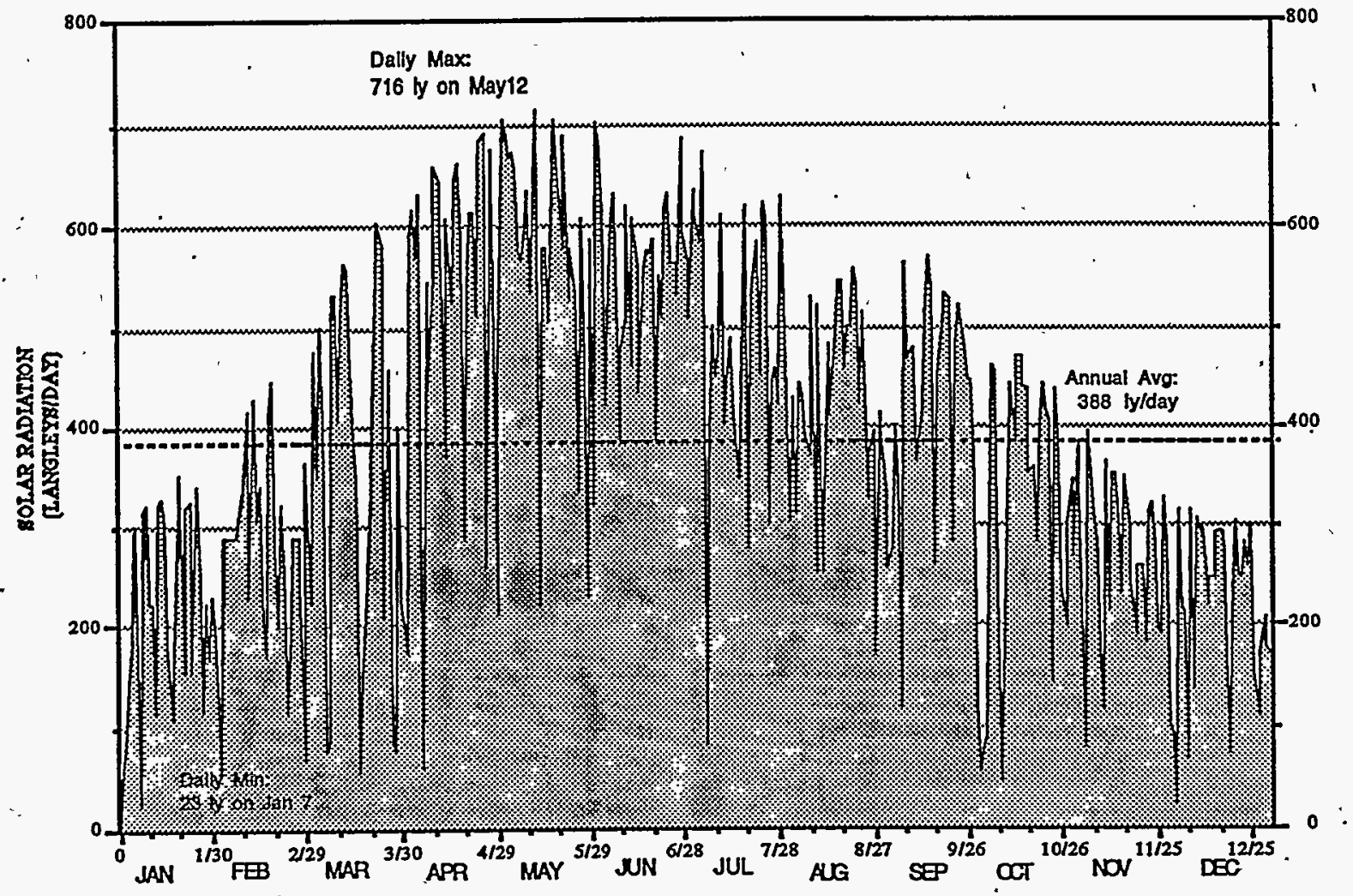




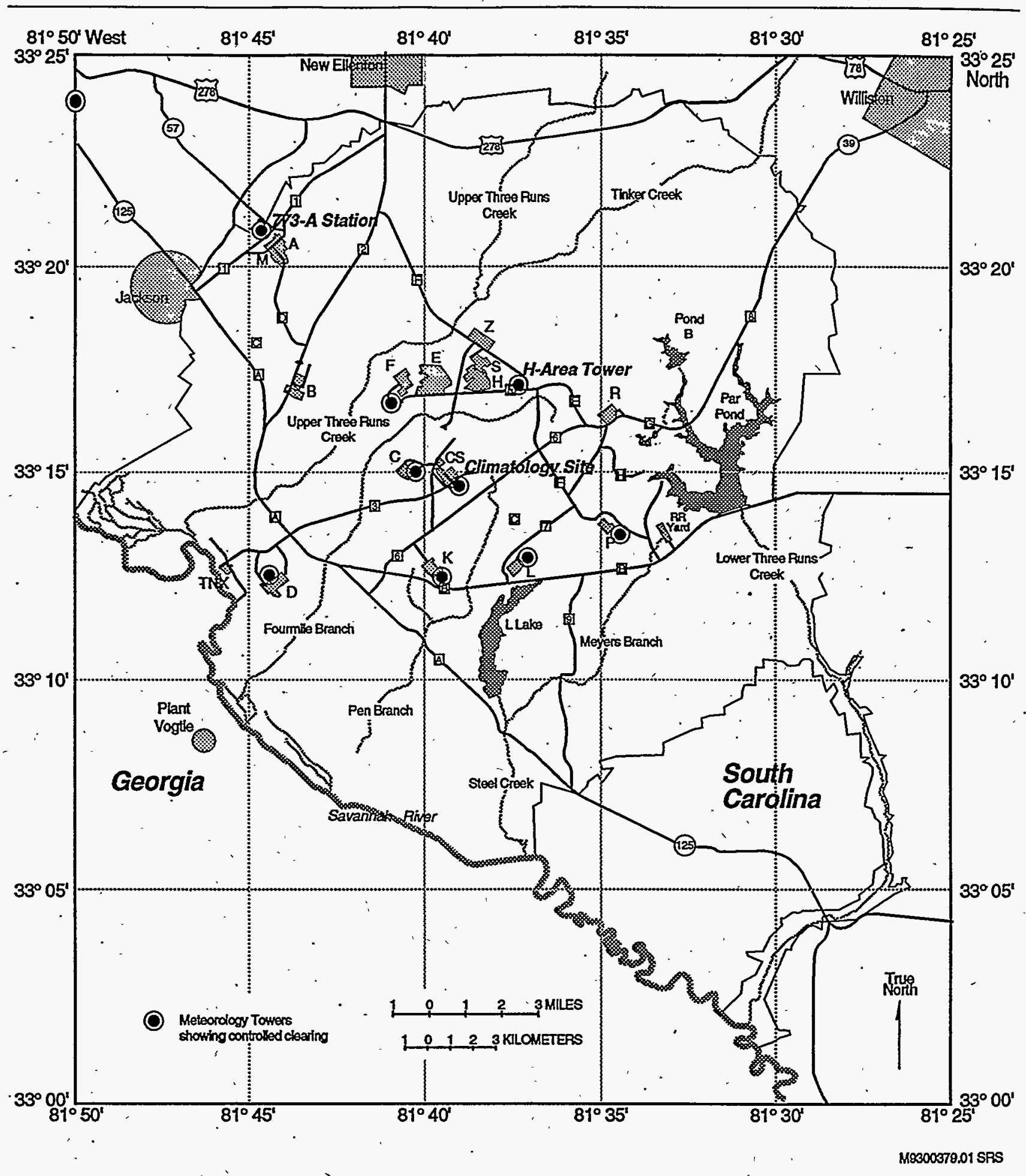

Attachment A. Map of the Savannah River Site Showing the Location of the Meteorological Towers 


\section{Appendix A. Joint Frequency Tables of Wind Speed by Wind Direction}

Appendix A-1. Occurrence Frequencies of Wind Direction Sector by Wind Speed Category for 1996, Central Climatology Tower, 61- Meters

\begin{tabular}{lccccccc} 
Direction & $0-2 \mathrm{~m} / \mathrm{s}$ & $2-4 \mathrm{~m} / \mathrm{s}$ & $4-6 \mathrm{~m} / \mathrm{s}$ & $6-8 \mathrm{~m} / \mathrm{s}$ & $8-12 \mathrm{~m} / \mathrm{s}$ & $>12 \mathrm{~m} / \mathrm{s}$ & TOTAL \\
\hline N &. .00596 & .01329 & .01098 & .00271 & .00054 & .00000 & .03348 \\
NNE & .00662 & .01910 & .01829 & .00605 & .00144 & .00000 & .05149 \\
NE & .00635 & .02563 & .02948 & .00857 & .00063 & .00000 & .07065 \\
ENE & .00677 & .02430 & .02346 & .00689 & .00057 & .00000 & .06199 \\
E & .00734 & .02376 & .02145 & .00244 & .00003 & .00009 & .05510 \\
ESE & .00752 & .01726 & .01772 & .00168 & .00003 & .00003 & .04424 \\
SE & .00743 & .01627 & .01928 & .00256 & .00018 & .00000 & .04572 \\
SSE & .00725 & .02048 & .02891 & .00731 & .00153 & .00000 & .06548 \\
S & .00680 & .02463 & .03444 & .00782 & .00138 & .00000 & .07507 \\
SSW & .00614 & .02740 & .02665 & .00782 & .00096 & .00000 & .06897 \\
SW & .00638 & .03032 & .03697 & .01116 & .00129 & .00003 & .08614 \\
WSW & .00611 & .03104 & .04265 & .01612 & .00454 & .00015 & .10061 \\
W & .00502 & .02933 & .03706 & .01714 & .00914 & .00039 & .09808 \\
WNW & .00529 & .02099 & .02539 & .01065 & .00626 & .00012 & .06870 \\
NW. & .00755 & .01874 & .01308 & .00208 & .00069 & .00003 & .04217 \\
NNW & .00722 & .01558 & .00731 & .00190 & .00009 & .00000 & .03209 \\
TOTAL &. .10572 & .35814 & .39309 & .11288 & .02933 & .00084 & 1.00000
\end{tabular}


Appendix A-2. Occurrence Frequencies of Wind Direction Sector by Wind Speed Category - 1987-91, H-Area Tower (supplemented), 61-m Level

\begin{tabular}{llllllll} 
Direction & $0-2 \mathrm{~m} / \mathrm{s}$ & $.2-4 \mathrm{~m} / \mathrm{s}$ & $4-6 \mathrm{~m} / \mathrm{s}$ & $6-8 \mathrm{~m} / \mathrm{s}$ & $8-12 \mathrm{~m} / \mathrm{s}$ & $>12 \mathrm{~m} / \mathrm{s}$ & TOTAL \\
\hline N & .00511 & .01497 & .01041 & .00121 & .00007 & .00000 & .03176 \\
NNE & .00614 & .02480 & .02426 & .00365 & .00043 & .00000 & .05928 \\
NE & .00653 & .04425 & .03601 & .00381 & .00030 & .00000 & .09089 \\
ENE & .00646 & .04050 & .02677 & .00180 & .00005 & .00000 & .07558 \\
E & .00584 & .02843 & .01812 & .00046 & .00005 & .00000 & .05289 \\
ESE & .00536 & .02608 & .01488 & .00082 & .00005 & .00000 & .04719 \\
SE & .00602 & .02562 & .01814 & .00089 & .00000 & .00000 & .05068 \\
SSE & .00559 & .02690 & .02779 & .00294 & .00037 & .00000 & .06360 \\
S & .00589 & .03254 & .03674 & .00507 & .00062 & .00000 & .08085 \\
SSW & .00536 & .03135 & .02759 & .00399 & .00087 & .00000 & .06916 \\
SW & .00657 & .03560 & .03144 & .00436 & .00064 & .00000 & .07861 \\
WSW & .00561 & .04128 & .03354 & .00500 & .00078 & .00002 & .08623 \\
W & .00641 & .03569 & .02759 & .00682 & .00228 & .00000 & .07879 \\
WNW & .00607 & .02809 & .02250 & .00719 & .00240 & .00002 & .06627 \\
NW & .00557 & .01898 & .01009 & .00201 & .00027 & .00000 & .03692 \\
NNW & .00605 & .01695 & .00723 & .00089 & .00018 & .000000 & .03176 \\
&. & & & &. & & \\
TOTAL & .09458 & .47205 & .37308 & .05091 & .00934 & .00005 & 1.00000
\end{tabular}


Appendix A-3. Occurrence Frequencies of Wind Direction Sect by Wind Speed Category for the Winter 1996, Central Climatology Tower, 61-m Level

Direction $\begin{array}{llllll}0-2 \mathrm{~m} / \mathrm{s} & 2-4 \mathrm{~m} / \mathrm{s} \quad 4-6 \mathrm{~m} / \mathrm{s} \quad 6-8 \mathrm{~m} / \mathrm{s} \quad 8-12 \mathrm{~m} / \mathrm{s} \quad<12 \mathrm{~m} / \mathrm{s} \quad \text { TOTAL }\end{array}$

\begin{tabular}{llllllll}
\hline N & .00258 & .00674 & .00754 & .00218 & .00020 & .00000 & .01924 \\
NNE & .00198 & .01250 & .01706 & .00476 & .00000 & .00000 & .03630 \\
NE & .00258 & .02063 & .01904 & .00099 & .00000 & .00000 & .04324 \\
ENE & .00377 & .02916 & .02896 & .01071 & .00020 & .00000 & .07280 \\
E & .00218 & .03194 & .03075 & .00595 & .00000 & .00000 & .07082 \\
ESE & .00278 & .01845 & .01587 & .00218 & .00000 & .00000 & .03928 \\
SE & .00317 & .00893 &. .01904 & .00417 & .00119 & .00000 & .03650 \\
SSE & .00397 & .01071 & .00913 & .00694 & .00674 & .00000 & .03749 \\
S & .00417 & .01547 & .02162 & .01032 & .00516 & .00000 & .05673 \\
SSW & .00298 & .01468 & .00952 & .01012 & .00139 & .00000 & .03868 \\
SW & .00298 & .01845 & .05257 & .02619 & .00000 & .00000 & .10018 \\
WSW & .00198 & .02539 & .06546 & .04245 & .01012 & .00000 & .14541 \\
W & .00198 & .02162 & .04285 & .04086 & .02519 & .00079 & .13331 \\
WNW & .00139 & .02539 & .03769 & .02420 & .01528 & .00060 & .10454 \\
NW & .00397 & .01627 & .01587 & .00536 & .00337 & .00000 & .04483 \\
NNW & .00317 & .01091 & .00536 & .00119 & .00000 & .00000 & .02063 \\
& .04563 & .28724 & .39833 & .19857 & .06884 & .00139 & 1.00000
\end{tabular}


Appendix A-4. Occurrence Frequencies of Wind Direction Sector by Wind Speed Category for the Spring 1996, Central Climatology Tower, 61-m Level

\begin{tabular}{|c|c|c|c|c|c|c|c|}
\hline Direction & $0-2 \mathrm{~m} / \mathrm{s}$ & $2-4 \mathrm{~m} / \mathrm{s}$ & $4-6 \mathrm{~m} / \mathrm{s}$ & $6-8 \mathrm{~m} / \mathrm{s}$ & $8-12 \mathrm{~m} / \mathrm{s}$ & $<12 \mathrm{~m} / \mathrm{s}$ & TOTAL \\
\hline $\mathbf{N}$ & .00385 & .01215 & .01528 & .00216 & .00084 & .00000 & .03428 \\
\hline NNE & .00541 & .01227 & .01612 & .00890 & .00180 & .00000 & .04450 \\
\hline NE & .00529 & 01034 & .01732 & $.00890:$ & .00084 & .00000 & .04270 \\
\hline ENE & .00517 & .01371 & .01311 & .00782 & .00180 & .00000 & .04162 \\
\hline$E$ & .00794 & .01479 & .01119 & .00204 & .00012 & .00036 & .03644 \\
\hline ESE & .00589 & .01227 & .01191 & .00265 & .00000 & .00012 & .03284 \\
\hline SE & .00469 & .01299 & .01756 & .00337 & .00000 & .00000 & .03861 \\
\hline SSE & .00313 & .01600 & .04330 & .00926 & .00096 & .00000 & .07265 \\
\hline$S$ & $.0027 ?$ & .02045 & .05376 & .00986 & .00060 & .00000 & .08744 \\
\hline SSW & .00421 & .02682 & .04258 & .01455 & .00229 & .00000 & .09045 \\
\hline sW & .00493 & .02718 & .04222 & .01516 & .00373 & .00012 & .09334 \\
\hline WSW & .00469 & .02682 & .04847 & .01961 & .00926 & .00060 & .10945 \\
\hline W & .00421 & .02875 & .04065 & .01780 & .01227 & .00096 & .10464 \\
\hline WNW & .00517 & .02117 & .03199 & .01083 & .00962 & .00000 & .07878 \\
\hline NW & .00674 & .02201 & .01660 & .00241 & .00012 & .00000 & .04787 \\
\hline NNW & .00770 & .02321 & .01034 & .00301 & .00012 & .00000 & .04438 \\
\hline TOTAL & .08179 & .30094 & .43240 & .13832 & .04438 & .00216 & 1.00000 \\
\hline
\end{tabular}


Appendix A-5. Occurrence Frequencies of Wind Direction Sector by Wind Speed Category for the Summer 1996, Central Climatology Tower, 61-m Level

\begin{tabular}{lccccccc} 
Direction & $0-2 \mathrm{~m} / \mathrm{s}$ & $2-4 \mathrm{~m} / \mathrm{s}$ & $4-6 \mathrm{~m} / \mathrm{s}$ & $6-8 \mathrm{~m} / \mathrm{s}$ & $8-12 \mathrm{~m} / \mathrm{s}$ & $<12 \mathrm{~m} / \mathrm{s}$ & TOTAL \\
\hline N & .00622 & .00576 & .00345 & .00299 & .00046 & .00000 & .01889 \\
NNE & .00622 & .01221 & .00737 & .00415 & .00081 & .00000 & .03075 \\
NE & .00610 & .02476 & .02522 & .00760 & .00000 & .00000 & .06369 \\
ENE & .00806 & .03133 & .02211 & .00265 & .00000 & .00000 & .06415 \\
E & .00818 & .03017 & .02142 & .00115 & .00000 & .00000 & .06092 \\
ESE & .00910 & .02269 & .01831 & .00058 & .00000 & .00000 & .05067 \\
SE & .01025 & .02511 & .01474 & .00196 & .00000 & .00000 & .05206 \\
SSE & .01221 & .03282 & .02948 & .00357 & .00012 & .000000 & .07820 \\
S & .01071 & .04261 & .03616 & .00161 & .00023 & .00000 & .09133 \\
SSW & .00806 & .04964 & .03040 & .00104 & .00023 & .00000 & .08937 \\
SW & .00864 & .05908 & .04653 & .00323 & .00012 & .00000 & .11759 \\
WSW & .01060 & .05447 & .04952 & .00633 & .00092 & .00000 & .12185 \\
W & .00806 & .04088 & .02937 & .00518 & .00012 & .00000 & .08361 \\
WNW & .00714 & .02084 & .00875 & .00173 & .00012 & .00012 & .03870 \\
NW & .00691 & .01290 & .00265 & .00035 & .00012 & .00000 & .02292 \\
NNW & .00518 & .00703 & .00230 & .00069 & .00012 & .00000 & .01532 \\
&. &. & & & & & \\
TOTAL & .13164 & .47230 & .34781 & .04480 & .00334 & .00012 & 1.00000
\end{tabular}


Appendix A-6. Occurrence Frequencies of Wind Direction Sector by Wind Speed Category for the Fall 1996, Central Climatology Tower, 61-m Level

\begin{tabular}{|c|c|c|c|c|c|c|c|}
\hline Direction & $0-2 \mathrm{~m} / \mathrm{s}$ & $2-4 \mathrm{~m} / \mathrm{s}$ & $4-6 \mathrm{~m} / \mathrm{s}$ & $6-8 \mathrm{~m} / \mathrm{s}$ & $8-12 \mathrm{~m} / \mathrm{s}$ & $>12 \mathrm{~m} / \mathrm{s}$ & TOTAL \\
\hline $\bar{N}$ & .01007 & .02390 & .01735 & .00400 & .00061 & .00000 & .05594 \\
\hline NNE & .01201 & .03737 & .03228 & .00752 & .00316 & .00000 & .09234 \\
\hline NE & .01007 & .04393 & .04890 & .01420 & .00170 & .00000 & .11880 \\
\hline ENE & .00813 & .02755 & .02961 & .00680 & .00036 & .00000 & .07244 \\
\hline$E$ & .00862 & .02318 & .02912 & .00133 & .00000 & .00000 & .06225 \\
\hline ESE : & .01116 & .01796 & .02488 & .00158 & .00012 & .00000 & .05570 \\
\hline SE & .00959 & .01711 & .02876 & .00182 & .00000 & .00000 & .05727 \\
\hline SSE & .00752 & .02208 & .02876 & .00886 & .00012 & .00000 & .06735 \\
\hline$S$ & .00825 & .01662 & .01990 & .00510 & .00049 & .00000 & .05036 \\
\hline ssw & .00667 & .01408 & .00983 & .00303 & .00036 & .00000 & .03398 \\
\hline SW & .00789 & .01505 & .01699 & .00510 & .00012 & .00000 & .04514 \\
\hline WSW & .00510 & .01456 & .02245 & .01092 & .00121 & .00000 & .05424 \\
\hline$w$ & $\therefore .00534$ & .02026 & .02985 & .01614 & .00534 & .00000 & .07693 \\
\hline WNW & .00631 & .01796 & .02755 & .01007 & .00316 & .00000 & .06504 \\
\hline NW & .00983 & .02269 & .01929 & .00146 & .00000 & .00000 & .05327 \\
\hline NNW & .01031 & .01529 & .01031 & .00303 & .00000 & .00000 & .03895 \\
\hline TOTAL & .13688 & .34959 & .39582 & .10096 & .01675 & .00000 & 1.00000 \\
\hline
\end{tabular}


Appendix A-7. Occurrence Frequencies of Wind Direction Sector by Wind Speed Category - Winter 1987-91, H-Area Tower (supplemented), 61-m Level

\begin{tabular}{lllllllll} 
Direction & $0-2 \mathrm{~m} / \mathrm{s}$ & $2-4 \mathrm{~m} / \mathrm{s}$ & $4-6 \mathrm{~m} / \mathrm{s}$ & $6-8 \mathrm{~m} / \mathrm{s}$ & $8-12 \mathrm{~m} / \mathrm{s}$ & $>12 \mathrm{~m} / \mathrm{s}$ & TOTAL \\
& & & & & & & & \\
\hline N & .00553 & .01520 & .01042 & .00159 & .00000 & .00000 & .03274 \\
NNE & .00765 & .03189 & .02540 & .00181 & .00000 & .00000 & .06675 \\
NE & .00861 & .05028 & .03784 & .00255 & .00021 & .00000 & .09949 \\
ENE & .00648 & .02817 & .02211 & .00149 & .00000 & .00000 & .05825 \\
E & .00638 & .01956 & .01201 & .00043 & .00000 & .00000 & .03837 \\
ESE & .00606 & .01966 & .00925 & .00011 & .00000 & .00000 & .03508 \\
SE & .00627 & .01552 & .01297 & .00021 & .00000 & .00000 & .03497 \\
SSE & .00404 & .01818 & .02179 & .00234 & $: .00000$ & .00000 & .04634 \\
S & .00468 & .02360 & .04326 & .00733 & .00085 & .00000 & .07972 \\
SSW & .00500 & .02583 & .03008 & .00617 & .00244 & .00000 & .06952 \\
SW & .00659 & .02838 & .03848 &. .00723 & .00064 & .00000 & .08131 \\
WSW & .00521 & .03370 & .04156 & .00670 & .00117 & .00000 & .08833 \\
W & .00563 & .03635 & .03922 & .01116 & .00468 & .00000 & .09705 \\
WNW & .00627 & .03646 & .03083 & .01201 & .00404 & .00011 & .08971 \\
NW & .00532 & .02434 & .01403 & .00340 & .00074 & .00000 & .04783 \\
NNW & .00521 & .02083 & .00797 & .00053 & .00000 & .000000 & .03454
\end{tabular}

$\begin{array}{lllllllll}\text { TOTAL } & .09492 & .42793 & .39722 & .06505 & .01477 & .00011 & 1.00000\end{array}$ 
Appendix A-8. Occurrence Frequencies of Wind Direction Sector by Wind Speed Category-Spring 1987-91, H-Area Tower (supplemented), 61-m Level

\begin{tabular}{|c|c|c|c|c|c|c|c|}
\hline Direction & $0-2 \mathrm{~m} / \mathrm{s}$ & $2-4 \mathrm{~m} / \mathrm{s}$ & $4-6 \mathrm{~m} / \mathrm{s}$ & $6-8 \mathrm{~m} / \mathrm{s}$ & $8-12 \mathrm{~m} / \mathrm{s}$ & $>12 \mathrm{~m} / \mathrm{s}$ & TOTAL \\
\hline $\mathbf{N}$ & .00362 & .01449 & .01033 & .00081 & .00000 & .00000 & .02926 \\
\hline NNE & .00417 & .01884 & .02201 & .00272 & .00009 & .00000 & .04783 \\
\hline NE & $.00408^{\circ}$ & .02853 & .02554 & .00272 & .00009 & .00000 & .06096 \\
\hline ENE & .00552 & .03143 & .02274 & .00100 & .00009 & .00000 & .06078 \\
\hline$E$ & -.00417 & .02482 & .01812 & .00027 & .00000 & .00000 & .04737 \\
\hline ESE & .00435 & .02364 & .01993 & .00217 & .00000 & .00000 & .05009 \\
\hline SE & .00507 & .02926 & .02473 & .00199 & .00000 & .00000 & .06105 \\
\hline SSE & .00489 & .03442 & .04312 & .00652 & .00127 & .00000 & .09022 \\
\hline$s$ & .00580 & .03324 & .04601 & .00770 & .00109 & .00000 & .09384 \\
\hline SSW & .00552 & .02880 & .03360 & .00471 & .00045 & .00000 & .07310 \\
\hline sw & .00462 & $.03207^{\circ}$ & .03768 & .00697 & .00145 & .00000 & .08279 \\
\hline WSW & .00435 & .03360 & .03505 & .00716 & .00127 & .00000 & .08143 \\
\hline w & .00471 & .03542 & .02609 & .00815 & .00308 & .00000 & .07745 \\
\hline WNW. & .00507 & .02600 & .02699 & .01105 & .00399 & .00000 & .07310 \\
\hline NW & .00435 & .01712 & .01259 & .00245 & .00000 & .00000 & .03650 \\
\hline NNW & $\begin{array}{l}.00562 \\
\therefore\end{array}$ & $.01839^{\circ}$ & .00969 & .00036 & .00018 & .00000 & .03424 \\
\hline TOTAL & .07591 & .43007 & .41422 & .06676 & .01304 & .00000 & 1.00000 \\
\hline
\end{tabular}


Appendix A-9. Occurrence Frequencies of Wind Direction Sector by Wind Speed Category-Summer 1987-91, H-Area Tower (supplemented), 61-m Level

\begin{tabular}{|c|c|c|c|c|c|c|c|}
\hline Direction & $0-2 \mathrm{~m} / \mathrm{s}$ & $2-4 \mathrm{~m} / \mathrm{s}$ & 4-6 m/s & $6-8 \mathrm{~m} / \mathrm{s}$ & $8-12 \mathrm{~m} / \mathrm{s}$ & $>12 \mathrm{~m} / \mathrm{s}$ & TOTAL \\
\hline $\bar{N}$ & .00707 & .01205 & .00272 & .00036 & .00000 & .00000 & .02219 \\
\hline NNE & .00743 & .02174 & .01087 & .00045 & .00000 & .00000 & .04049 \\
\hline NE & .00888 & .04112 & .01232 & .00063 & .00000 & .00000 & .06295 \\
\hline ENE & .00815 & .04203 & .01404 & .00063 & .00000 & .00000 & .06486 \\
\hline$E$ & .00752 & .03496 & .01069 & .00045 & .00009 & .00000 & .05371 \\
\hline ESE & .00670 & .03813 & .01196 & .00027 & .00000 & .00000 & .05707 \\
\hline SE & .00824 & .03496 & .01341 & .00027 & .00000 & .00000 & .05688 \\
\hline SSE & .00806 & .03804 & .02554 & .00054 & .00000 & .00000 & .07219 \\
\hline s & .00978 & .05462 & $.03460^{-}$ & .00127 & .00009 & .00000 & .10036 \\
\hline ssw & .00833 & .05643 & .02917 & .00217 & .00018 & .00000 & .09629 \\
\hline sw & .01015 & .06295 & .02817 & .00072 & .00018 & .00000 & .10217 \\
\hline WSW & .00806 & .07237 & .02591 & .00172 & .00000 & .00000 & .10806 \\
\hline$w$ & .00833 & .04764 & .01685 & .00054 & .00000 & .00000 & .07337 \\
\hline WNW & .00806 & .02563 & .01005 & .00036 & .00018 & .00000 & .04429 \\
\hline Niw & .00652 & .01486 & .00245 & .00009 & .00000 & .00000 & .02391 \\
\hline NNW & .00788 & .01078 & .00217 & .00036 & .00000 & .00000 & .02119 \\
\hline TOTAL & 12917 & .60833 & .25091 & .01087 & .00072 & .00000 & 1.00000 \\
\hline
\end{tabular}


Appendix A-10. Occurrence Frequencies of Wind Direction Sector by Wind Speed Category - Fall 1987-91, H-Area Tower (supplemented), 61-m Level

$$
\text { Direction. } 0-2 \mathrm{~m} / \mathrm{s} \quad 2-4 \mathrm{~m} / \mathrm{s} \quad 4-6 \mathrm{~m} / \mathrm{s} . \quad 6-8 \mathrm{~m} / \mathrm{s} \quad 8-12 \mathrm{~m} / \mathrm{s} \quad>12 \mathrm{~m} / \mathrm{s} \quad \text { TOTAL }
$$

\begin{tabular}{llllllll}
\hline N & .00568 & .01914 & .01612 & .00174 & .00018 & .00000 & .04286 \\
NNE & .00668 & .03040 & .03791 & .00659 & .00037 & .00000 & .08196 \\
NE & .00751 & .06016 & .05861 & .00504 & .00009 & .00000 & .13141 \\
ENE & .00833 & .05852 & .04039 & .00275 & .00009 & .00000 & .11007 \\
E & .00678 & .03581 & .02811 & .00037 & .00009 & .00000 & .07116 \\
ESE & .00687 & .02509 & .01648 & .00018 & .00018 & .00000 & .04881 \\
SE & .00678 & .02418 & .02005 & .00073 & .00000 & .00000 & .05174 \\
SSE & .00659 & .02079 & .01886 & .00119 & .00009 & .00000 & .04753 \\
S & .00531 & .02308 & .02180 & .00275 & .00027 & .00000 & .05321 \\
SSW & .00467 & .01804 & .01465 & .00229 & .00046 & .00000 & .04011 \\
SW & .00678 & .02344 & .02033 & .00201 & .00018 & .00000 & .05275 \\
WSW & .00769 & .03214 & .02665 & .00302 & .00037 & .00009 & .06996 \\
W & .00870 & .02729 & .02317 & .00375 & .00092 & .00000 & .06383 \\
WNW & .00769 & .02866 & .01832 & .00302 & .00146 & .00000 & .05916 \\
NW & .00760 & .02115 & .00925 & .00119 & .00027 & .00000 & .03947 \\
NNW & .00714 & .01950 & .00733 & .00146 & .00055 & .00000 & .03599 \\
& & &. & & &. & \\
TOTAL & .11081 & .46740 & .37802 & .03809 & .00559 & .00009 & 1.00000
\end{tabular}


Appendix A-11. Occurrence Frequencies of Wind Direction Sector by Wind Speed Category for 1996, A-Area Tower, 61-m Level

\begin{tabular}{llllllll} 
Direction & $0-2 \mathrm{~m} / \mathrm{s}$ & $2-4 \mathrm{~m} / \mathrm{s}$ & $4-6 \mathrm{~m} / \mathrm{s}$ & $6-8 \mathrm{~m} / \mathrm{s}$ & $\mathbf{8 - 1 2} \mathrm{m} / \mathrm{s}$ & $>12 \mathrm{~m} / \mathrm{s}$ & TOTAL \\
& & & & & & & \\
\hline N & .00519 & .01686 & .00773 & .00110 & .00012 & .00000 & .03100 \\
NNE & .00367 & .01479 & .01591 & .00427 & .00068 & .00000 & .03932 \\
NE & .00367 & .02092 & .03239 & .01031 & .00095 & .00000 & .06824 \\
ENE & .00385 & .02421 & .03025 & .00681 & .00038 & .00000 & .06552 \\
E & .00486 & .02726 & .02729 & .00136 & .00000 & .00000 & .06078 \\
ESE & .00521 & .02625 & .01917 & .00154 & .00003 & .00000 & .05221 \\
SE & .00720 & .02350 & .01926 & .00462 & .00083 & .00003 & .05544 \\
SSE & .00628 & .02560 & .02373 & .00791 & .00293 & .00012 & .06658 \\
S & .00581 & .02376 & .02658 & .00578 & .00139 & .00003 & .06335 \\
SSW & .00510 & .03369 & .02901 & .00613 & .00065 & .00003 & .07462 \\
SW & .00519 & .03452 & .03787 & .00605 & .00104 & .00000 & .08466 \\
WSW & .00539 & .03689 & .04249 & .00687 & .00201 & .00003 & .09370 \\
W & .00495 & .03354 & .03426 & .01378 & .00572 & .00012 & .09237 \\
WNW & .00441 & .02302 & .02765 & .01331 & .00699 & .00000 & .07538 \\
NW & .00516 & .01467 & .01882 & .00439 & .00122 & .00006 & .04430 \\
NNW & .00462 & .01381 & .01162 & .00169 & .00015 & .00000 & .03188 \\
& & & & & & & \\
TOTAL & .08057 & .39331 & .40404 & .09592 & .02510 & .00042 & .99935
\end{tabular}


Appendix A-12. Occurrence Frequencies of Wind Direction Sector by Wind Speed Category for 1996, C-Area Tower, 61-m Level

Direction $0-2 \mathrm{~m} / \mathrm{s} \quad 2-4 \mathrm{~m} / \mathrm{s} \quad 4-6 \mathrm{~m} / \mathrm{s} \quad 6-8 \mathrm{~m} / \mathrm{s} \quad 8-12 \mathrm{~m} / \mathrm{s} \quad>12 \mathrm{~m} / \mathrm{s} \quad$ TOTAL

\begin{tabular}{llllllll}
\hline N & .00468 & .01360 & .00889 & .00210 & .00027 & .00000 & .02954 \\
NNE & .00540 & .01927 & .01843 & .00627 & .00153 & .00003 & .05094 \\
NE & .00579 & .02786 & .03756 & .01579 & .00141 & .00000 & .08841 \\
ENE & .00753 & .03065 & .01960 & .00201 & .00012 & .00000 & .05992 \\
E & .00594 & .02471 & .02293 & .00249 & .00003 & .00003 & .05614 \\
ESE & .00477 & .01522 & .01867 & .00345 & .00009 & .00000 & .04221 \\
SE & .00618 & .01696 & .02183 & .00555 & .00036 & .00000 & .05088 \\
SSE & .00591 & .01852 & .02870 & .01258 & .00183 & .00000 & .06754 \\
S & .00663 & .02486 & .03362 & .00759 & .00144 & .00000 & .07415 \\
SSW & .00633 & .02693 & .02585 & .00657 & .00093 & .00003 & .06664 \\
SW & .00612 & .03584 & .04194 & .01642 & .00264 & .00009 & .10306 \\
WSW & .00534 & .02996 & .04032 & .01336 & .00537 & .00048 & .09483 \\
W & .00624 & .03434 & .03317 & .01282 & .00747 & .00024 & .09429 \\
WNW & .00390 & .01873 & .02315 & .00817 & .00489 & .00009 & .05893 \\
NW & .00378 & .01228 & .01558 & .00315 & .00087 & .00000 & .03566 \\
NNW & .00465 & .01000 & .00967 & .00153 & .00015 & .00003 &. .02603 \\
$\quad$ & & &. & & & & \\
TOTAL & .08925 & .35973 & .39990 & .11987 & .02942 & .00102 & .99919
\end{tabular}


Appendix A-13. Occurrence Frequencies of Wind Direction Sector by Wind Speed Category for 1996, D-Area Tower, 61-m Level

Direction $0-2 \mathrm{~m} / \mathrm{s} \quad 2-4 \mathrm{~m} / \mathrm{s} \quad 4-6 \mathrm{~m} / \mathrm{s} \quad 6-8 \mathrm{~m} / \mathrm{s} \quad 8-12 \mathrm{~m} / \mathrm{s} \quad>12 \mathrm{~m} / \mathrm{s}$ TOTAL

\begin{tabular}{llllllll}
\hline N & .01039 & .02089 & .00492 & .00057 & .00006 & .00000 & .03683 \\
NNE & .00865 & .02614 & .01000 & .00304 & .00054 & .00000 & .04837 \\
NE & .00919 & .03133 & .02495 & .00546 & .00054 & .00003 & .07150 \\
ENE & .01015 & .03133 & .01650 & .00206 & .00021 & .00000 & .06025 \\
E & .01000 & .02790 & .00991 & .00036 & .00000 & .00000 & .04817 \\
ESE & .00928 & .02417 & .00880 & .00033 & .00006 & .00000 & .04265 \\
SE & .01104 & .03193 & .01740 & .00233 & .00024 & .00000 & .06294 \\
SSE & .01071 & .03557 & .02432 & .00573 & .00233 & .00006 & .07873 \\
S & .01158 & .03128 & .01256 & .00337 & .00155 & .00006 & .06040 \\
SSW & .01218 & .03447 & .01522 & .00367 & .00072 & .00000 & .06625 \\
SW & .01116 & .03519 & .02080 & .00465 & .00069 & .00000 & .07249 \\
WSW & .00925 & .03325 & .02671 & .00469 & .00119 & .00000 & .07508 \\
W & .01164 & .03826 & .02122 & .00719 & .00349 & .00006 & .08186 \\
WNW & .01021 & .03026 & .02701 & .01113 & .00457 & .00000 & .08317 \\
NW & .01051 & .02492 & .01955 & .00624 & .00197 & .00000 & .06318 \\
NNW & .01080 & .02426 & .01086 & .00128 & .00003 & .00000 & .04724 \\
& & &. & & & &. \\
TOTAL & .16673 & .48116 & .27073 & .06210 & .01818 & .00021 & .99911
\end{tabular}


Appendix A-14. Occurrence Frequencies of Wind Direction Sector by Wind Speed Category for 1996, D-Area Tower, 61-m Level

Direction $\quad 0-2 \mathrm{~m} / \mathrm{s} \quad 2-4 \mathrm{~m} / \mathrm{s} \quad 4-6 \mathrm{~m} / \mathrm{s} \quad 6-8 \mathrm{~m} / \mathrm{s} \quad 8-12 \mathrm{~m} / \mathrm{s} \quad>12 \mathrm{~m} / \mathrm{s} \quad$ TOTAL

\begin{tabular}{llllllll}
\hline N & .00447 & .01051 & .00779 & .00169 & .00022 & .00000 & .02469 \\
NNE & .00476 & .01708 & .01699 & .00576 & .00250 & .00000 & .04709 \\
NE & .00814 & .04506 & .03520 & .01286 & .00147 & .00000 & .10272 \\
ENE & .00682 & .02566 & .02716 & .00839 & .00197 & .00000 & .07000 \\
E & .00557 & .02206 & .02212 & .00200 & .00003 & .00003 & .05182 \\
ESE & .00513 & .01849 & .01608 & .00128 & .00006 & .00000 & .04105 \\
SE & .00635 & .01787 & .01946 & .00313 & .00003 & .00000 & .04684 \\
SSE & .00688 & .02162 & .02700 & .00729 & .00091 & .00006 & .06377 \\
S & .00691 & .02466 & .03066 & .00623 & .00119 & .00000 & .06965 \\
SSW & .00657 & .02206 & .02422 & .00569 & .00100 & .00003 & .05958 \\
SW & .00738 & .03589 & .03996 & .01245 & .00109 & .00000 & .09678 \\
WSW & .00676 & .03623 & .04362 & .01264 & .00250 & .00016 & .10191 \\
W & .00720 & .03066 & .03730 & .01464 & .00842 & .00034 & .09856 \\
WNW & .00510 & .01949 & .02422 & .00914 & .00460 & .00000 & .06255 \\
NW & .00397 & .01270 & .01596 & .00288 & .00053 & .00006 & .03611 \\
NNW & .00441 & .01026 & .01023 & .00157 & .00003 & .00000 & .02650 \\
& &. &. & & & & \\
TOTAL & .09644 & .37032 & .39798 & .10764 & .02656 & .00069 & .99963
\end{tabular}


Appendix A-15. Occurrence Frequencies of Wind Direction Sector by Wind Speed Category for 1996, H-area Tower, 61-m Level

$\begin{array}{llllllll}\text { Direction } \quad 0-2 \mathrm{~m} / \mathrm{s} & 2-4 \mathrm{~m} / \mathrm{s} \quad 4-6 \mathrm{~m} / \mathrm{s} \quad 6-8 \mathrm{~m} / \mathrm{s} \quad 8-12 \mathrm{~m} / \mathrm{s} \quad>12 \mathrm{~m} / \mathrm{s} \quad \text { TOTAL }\end{array}$

\begin{tabular}{llllllll}
\hline N & .00569 & .01508 & .01071 & .00175 & .00018 & .00006 & .03349 \\
NNE & .00733 & .02315 & .02065 & .00412 & .00055 & .00000 & .05580 \\
NE & .00806 & .03977 & .02598 & .00320 & .00018 & .00000 & .07719 \\
ENE & .00637 & .02921 & .01745 & .00197 & .00000 & .00000 & .05500 \\
E & .00668 & .02792 & .02007 & .00068 & .00009 & .00000 & .05543 \\
ESE & .00585 & .01967 & .01816 & .00120 & .00000 & .00000 & .04488 \\
SE & .00523 & .02019 & .02222 & .00182 & .00034 & .00000 & .04980 \\
SSE & .00656 & .02188 & .02496 & .00692 & .00157 & .00003 & .06193 \\
S & .00686 & .02980 & .03650 & .00711 & .00126 & .00000 & .08154 \\
SSW & .00612 & .02936 & .02853 & .00619 & .00058 & .00000 & .07079 \\
SW & .00628 & .03841 & .04121 & .00899 & .00135 & .00000 & .09625 \\
WSW & .00548 & .03961 & .04131 & .00856 & .00286 & .00009 & .09791 \\
W & .00523 & .03413 & .03013 & .01305 & .00403 & .00012 & .08671 \\
WNW & .00486 & .02428 & .02493 & .00920 & .00292 & .00000 & .06621 \\
NW & .00514 & .01545 & .01373 & .00206 & .00068 & .00000 & .03706 \\
NNW & .00563 & .01493 & .00745 & .00135 & .00006 & .00000 & .02943 \\
& & & &. & &. & \\
TOTAL & .09739 & .42285 & .38401 & .07818 & .01668 & .00031 & .99941 \\
\hline
\end{tabular}


Appendix A-16. Occurrence Frequencies of Wind Direction Sector by Wind Speed Category for 1996, K-Area Tower, 61-m Level

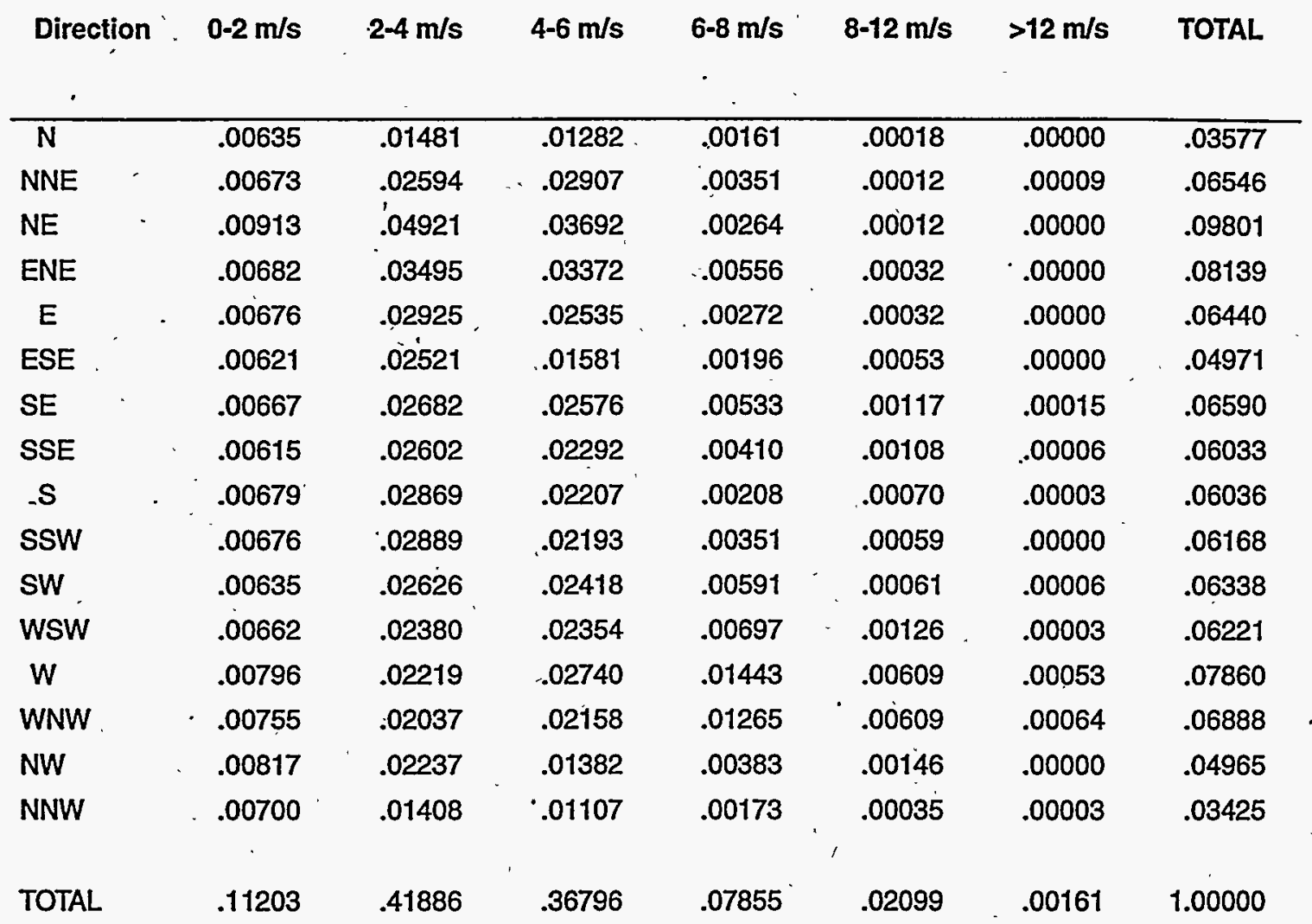


Appendix A-17. Occurrence Frequencies of Wind Direction Sector by Wind Speed Category for 1996, L-Area Tower, 61-m Level

Direction $\quad 0-2 \mathrm{~m} / \mathrm{s} \quad 2-4 \mathrm{~m} / \mathrm{s} \quad 4-6 \mathrm{~m} / \mathrm{s} \quad 6-8 \mathrm{~m} / \mathrm{s} \quad 8-12 \mathrm{~m} / \mathrm{s} \quad>12 \mathrm{~m} / \mathrm{s} \quad$ TOTAL

\begin{tabular}{|c|c|c|c|c|c|c|c|}
\hline $\bar{N}$ & .00545 & .01359 & .01006 & .00247 & .00009 & .00000 & .03166 \\
\hline NNE & .00449 & .01792 & .01853 & .00587 & .00166 & .00000 & .04847 \\
\hline NE & .00563 & .02756 & .03952 & .01931 & .00108 & .00000 & .09311 \\
\hline ENE & .00467 & .02711 & .02964 & .00675 & .00033 & .00006 & .06855 \\
\hline$E$ & .00542 & .02352 & .02286 & .00 .108 & .00012 & .00000 & .05301 \\
\hline ESE & .00518 & .01497 & .01509 & .00096 & .00003 & .00000 & .03624 \\
\hline SE & .00566 & .01765 & .01901 & .00247 & .00048 & .00000 & .04527 \\
\hline SSE & .00569 & .02118 & .02401 & .00473 & .00129 & .00000 & .05690 \\
\hline s. & .00699 & .03422 & .02892 & .00413 & .00132 & .00000 & .07558 \\
\hline SSW & .00777 & .04380 & .02949 & .00952 & .00208 & .00000 & .09265 \\
\hline sw & .00723 & .03654 & .03190 & .01166 & .00283 & .00009 & .09024 \\
\hline WSW & .00578 & .03214 & .03452 & .01211 & .00440 & .00036 & .08931 \\
\hline$W$ & .00569 & .03479 & .03024 & .01229 & .00455 & .00000 & .08756 \\
\hline WNW & .00419 & .02084 & .02621 & .00846 & .00395 & .00003 & .06368 \\
\hline NW & .00416 & .01328 & .01533 & .00352 & .00030 & .00003 & .03663 \\
\hline NNW & .00512 & .01286 & .01075 & .00154 & .00012 & .00000 & .03039 \\
\hline TOTAL & .08913 & .39197 & .38607 & .10687 & .02464 & .00057 & .99925 \\
\hline
\end{tabular}


Appendix A-18. Occurrence Frequencies of Wind Direction Sector by Wind Speed Category for 1996, P-Area Tower, 61-m Level

\begin{tabular}{|c|c|c|c|c|c|c|c|}
\hline Direction & $0-2 \mathrm{~m} / \mathrm{s}$ & $2-4 \mathrm{~m} / \mathrm{s}$ & $4-6 \mathrm{~m} / \mathrm{s}$ & $6-8 \mathrm{~m} / \mathrm{s}$ & $8-12 \mathrm{~m} / \mathrm{s}$ & $<12 \mathrm{~m} / \mathrm{s}$ & TOTAL \\
\hline $\mathbf{N}$ & .00477 & .01198 & .00949 & .00288 & .00036 & .00000 & .02947 \\
\hline NNE & .00451 & .01746 & .01939 & .00557 & .00148 & .00000 & .04841 \\
\hline NE & .00652 & .02879 & .03703 & .01551 & .00252 & .00000 & .09036 \\
\hline ENE & .00768 & .03786 & .02155 & .00231 & .00009 & .00003 & .06952 \\
\hline$E$ & .00634 & .02152 & .02016 & .00083 & .00006 & .00003 & .04895 \\
\hline ESE & .00543 & .01767 & .01358 & .00095 & .00003 & .00000 & .03765 \\
\hline SE & .00560 & .01802 & .01826 & .00237 & .00018 & .00000 & .04444 \\
\hline SSE & .00655 & .01797 & .02289 & .00457 & .00107 & .00000 & .05304 \\
\hline$S$ & .00596 & .02493 & .03824 & .00910 & .00243 & .00000 & .08067 \\
\hline ssw & .00587 & .02621 & .03712 & .00818 & .00128 & .00000 & .07865 \\
\hline sw & .00459 & .03214 & .04494 & .01230 & .00110 & .00000 & .09507 \\
\hline WSW & .00454 & .02873 & .04227 & .01272 & .00279 & .00000 & .09104 \\
\hline$w$ & .00483 & .02659 & .03774 & .01651 & .00697 & .00012 & .09276 \\
\hline WNW & .00371 & .01969 & .02638 & .01313 & . .00617 & .00009 & .06916 \\
\hline NW & .00323 & .01242 & .01788 & .00599 & .00175 & .00006 & .04132 \\
\hline NNW & .00356 & .01112 & .01079 & .00341 & .00018 & .00006 & .02911 \\
\hline TOTAL & .08369 & .35308 & .41770 & .11633 & .02843 & .00039 & .99962 \\
\hline
\end{tabular}

